\title{
One-pot Construction of 1-Phenylchromeno[3,4-b]pyrrol-4(3H)-one: Application to Total Synthesis of Ningalin B and a Pyrrolocoumarin- Based Electrochromic Switch
}

\author{
Chun-Ku Wu, Zhiqiang Weng,* and Ding-Yah Yang*
}

\section{Supporting Information}

\section{Table of Contents}

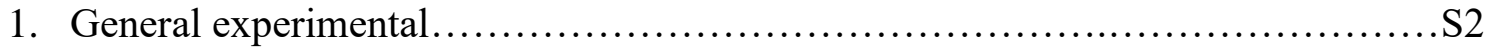

2. X-ray crystal structures of compounds $8, \mathbf{1 1}$, and $25 \ldots \ldots \ldots \ldots \ldots \ldots \ldots \ldots \ldots . . . . . . . \ldots \ldots$

3. Electrochemistry Studies.................................................................................... 5

4. Experimental procedure of synthesized compounds..............................S6

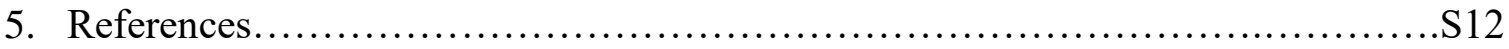

6. Copies of ${ }^{1} \mathrm{H}$ and ${ }^{13} \mathrm{C}$ NMR spectra of synthesized compounds....................... 13

7. Proton NMR spectrum comparison of ningalin B with literature...................S39 


\section{General experimental}

Melting points were determined on a Mel-Temp melting point apparatus in open capillaries and are uncorrected. MS were performed on JEOL JMS-SX/SX 102A spectrometer. IR spectra were obtained using a 1725XFT-IR spectrophotometer. Absorption spectra were acquired using an HP8453 spectrophotometer. Single crystal structures were determined by a Bruker AXS SMART-1000 X-ray single-crystal diffractometer. Cyclic voltammetric measurements were carried out on $\mathrm{CH}$ Instrument 611c system with platinum as the working and counter electrodes, and $\mathrm{Ag}$ wire (or SCE) as the reference electrode, and $n$ $\mathrm{Bu}_{4} \mathrm{NPF}_{6}$ as the supporting electrolyte. ${ }^{1} \mathrm{H}$ and ${ }^{13} \mathrm{C}$ NMR spectra were recorded at 400 and $100 \mathrm{MHz}$ on a BRUKER Ascend TM $400 \mathrm{MHz}$ spectrometer and ${ }^{13} \mathrm{C}$ NMR spectra was recorded at $150 \mathrm{MHz}$ on VARIAN INOVA 600. Chemical shifts were reported in parts per million on the $\delta$ scale relative to an internal standard (tetramethylsilane, or appropriate solvent peaks) with coupling constants given in hertz. ${ }^{1} \mathrm{H}$ NMR multiplicity data are denoted by s (singlet), d (doublet), t (triplet), q (quartet), and m (multiplet). Analytical thinlayer chromatography (TLC) was carried out on Merck silica gel 60G-254 plates ( $25 \mathrm{~mm}$ ) and developed with the solvents mentioned. Flash chromatography was performed in columns of various diameters with Merck silica gel (230-400 mesh ASTM 9385 kieselgel $60 \mathrm{H})$ by elution with the solvent systems. Solvents, unless otherwise specified, were reagent grade and distilled once prior to use. All new compounds exhibited satisfactory spectroscopic and analytical data.

The following abbreviations are used: ACN: acetonitrile; Hex: hexane; EtOAc: ethyl acetate; DCM: dichloromethane; DMF: dimethylformamide; MeOH: methanol; THF: tetrahydrofuran; TBAPF6: tetrabutylammonium hexafluorophosphate. 
2. X-ray crystal structures of compounds 8, 11, and 25 .

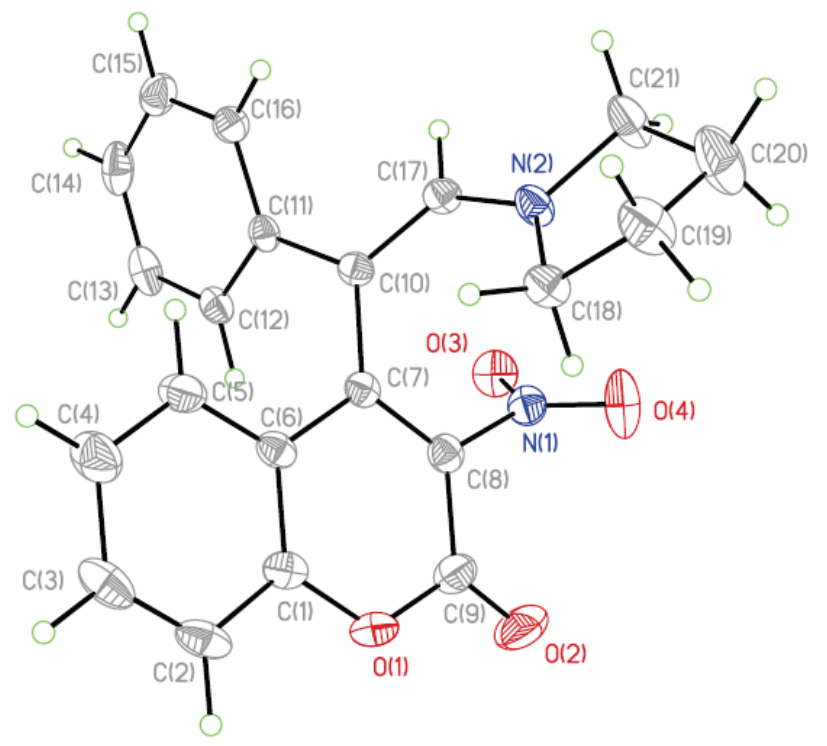

Figure S1. X-ray crystal structure of compound $\mathbf{8}$.

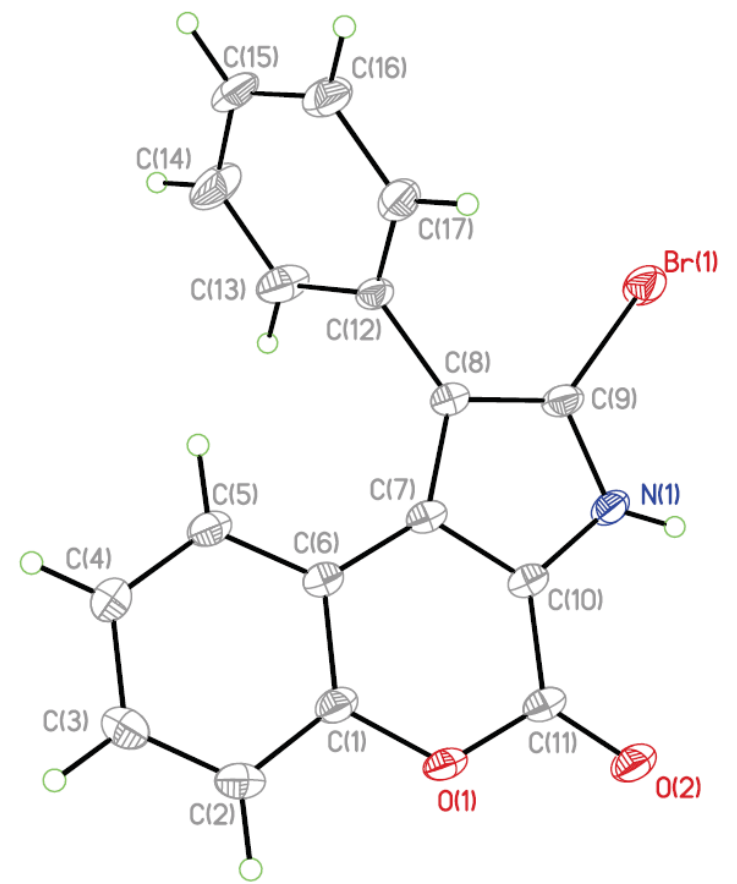

Figure S2. X-ray crystal structure of compound 11. 


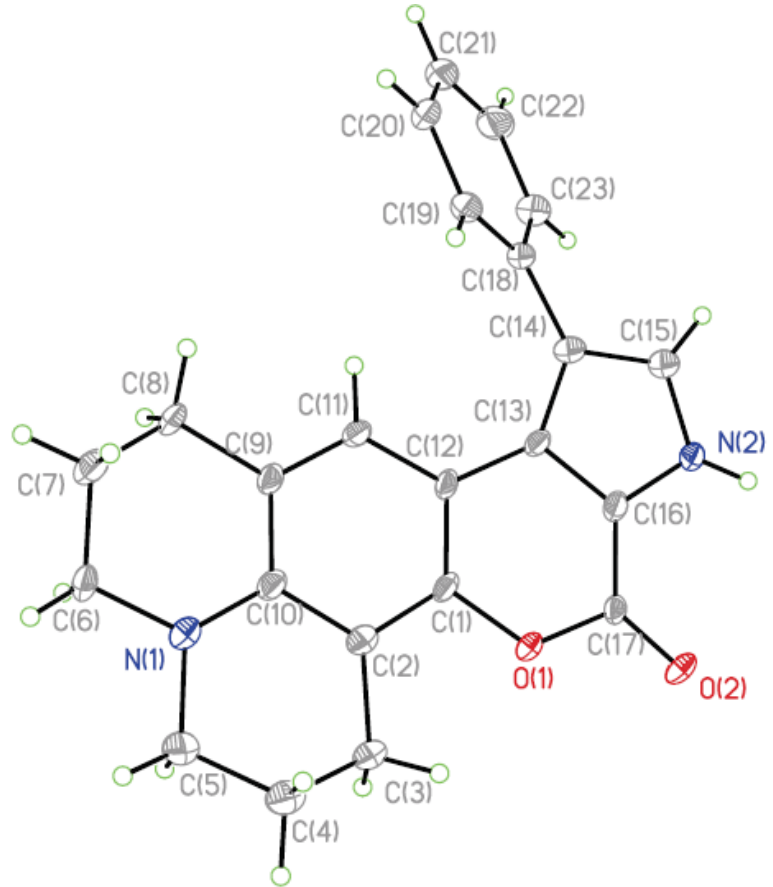

Figure S3. X-ray crystal structure of compound 25. 


\section{Electrochemistry Studies.}

Electrochemistry was performed with a three-electrode (SEC-C Thin Layer Quartz Glass Spectroelectrochemical cell kit $(\mathrm{Pt}))$ potentiostat in ACN with $0.1 \mathrm{M} \mathrm{TBAPF}_{6}$ deoxygenated by purging with nitrogen gas. Cyclic voltammetry was conducted with SECC Thin Layer Quartz Glass Cell equipped with SEC-C Pt Gauze as the working electrode, SEC-C Pt as the counter electrode, and RE-7 non aqueous (ACN) reference electrode $(\mathrm{Ag} / \mathrm{AgCl})$ as reference electrode.

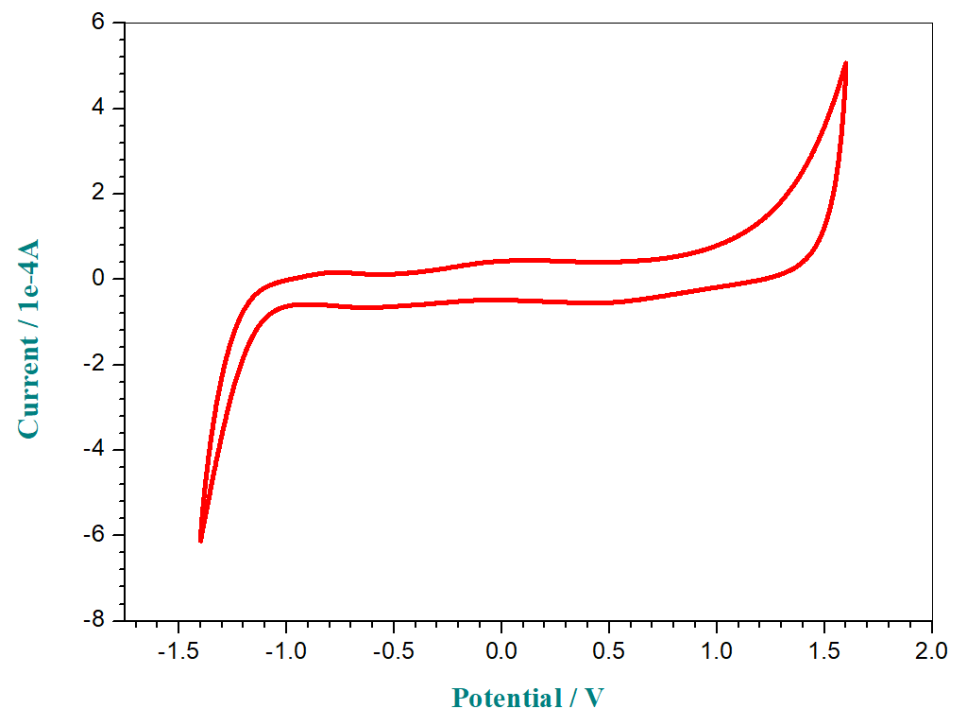

Figure S4. Cyclic voltammogram with $0.1 \mathrm{M} \mathrm{TBAPF}_{6}$ as supporting electrolyte at a scan rate of $100 \mathrm{mV} / \mathrm{s}$ in acetonitrile.

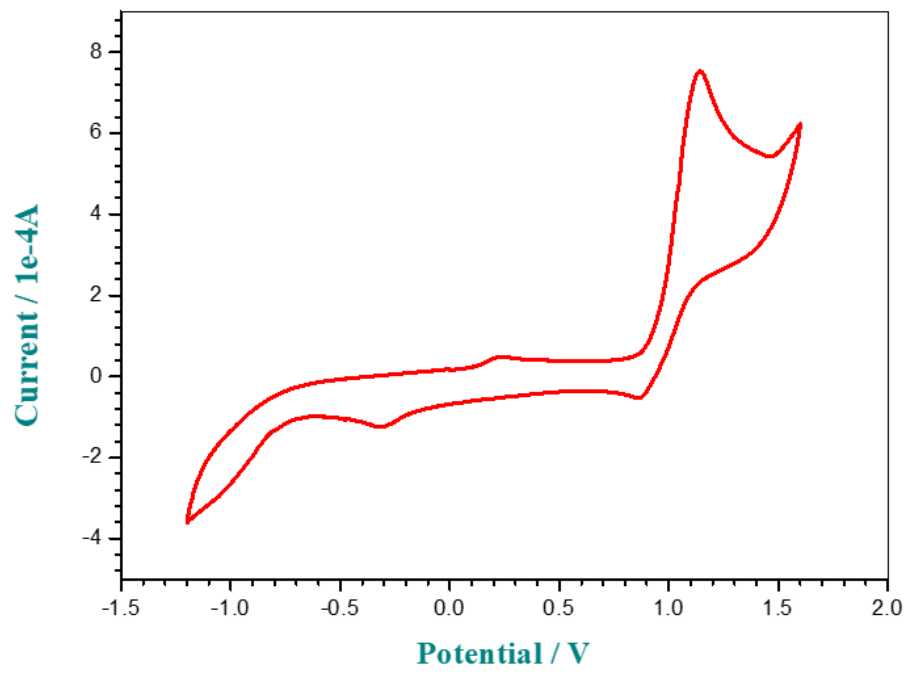

Figure S5. Cyclic voltammogram of $\mathbf{1 2}$ in acetonitrile with $0.1 \mathrm{M} \mathrm{TBAPF}_{6}$ as supporting electrolyte at a scan rate of $100 \mathrm{mV} / \mathrm{s}$. 


\section{Experimental procedure of synthesized compounds.}

(Z)-3-Nitro-4-(1-phenyl-2-(pyrrolidin-1-yl)vinyl)-2H-chromen-2-one (8).

To a solution of 2-phenylacetaldehyde (4,120 mg, $1 \mathrm{mmol})$, pyrrolidine (6, $71 \mathrm{mg}, 1 \mathrm{mmol})$, and a catalytic amount of $p$-toluenesulfonic acid ( 0.05 equiv) in dry dichloromethane (10 $\mathrm{mL})$ was stirred at room temperature for $8 \mathrm{~h}$. The 4-chloro-3-nitrocoumarin (3, $225 \mathrm{mg}, 1$ $\mathrm{mmol})$ in dry dichloromethane $(10 \mathrm{~mL})$ was then added dropwise to the mixture and the resulting mixture was stirred at room temperature for $5 \mathrm{~min}$. After completion of the reaction, the solvent was concentrated in vacuo and the crude product was purified by column chromatography (Hex/EtOAc, 7:1) to obtain the title compound as a red solid (333 mg, yield 92\%). mp $138-139{ }^{\circ} \mathrm{C} ;{ }^{1} \mathrm{H} \mathrm{NMR}\left(\mathrm{CDCl}_{3}, 400 \mathrm{MHz}\right) \delta 7.51(\mathrm{t}, J=8.0 \mathrm{~Hz}, 1 \mathrm{H})$, $7.46(\mathrm{~d}, J=8.0 \mathrm{~Hz}, 1 \mathrm{H}), 7.36(\mathrm{~d}, J=8.0 \mathrm{~Hz}, 1 \mathrm{H}), 7.26-7.22(\mathrm{~m}, 2 \mathrm{H}), 7.15-7.11(\mathrm{~m}, 4 \mathrm{H})$, $6.93(\mathrm{~s}, 1 \mathrm{H}), 3.14(\mathrm{bs}, 4 \mathrm{H}), 1.84(\mathrm{~s}, 4 \mathrm{H}) ;{ }^{13} \mathrm{C} \mathrm{NMR}\left(\mathrm{CDCl}_{3}, 100 \mathrm{MHz}\right) \delta 154.5,152.2,148.3$, $141.8,139.7,136.8,133.0,130.0,128.7,127.1,125.9$, 125.2 , 119.3, 117.4, 98.0, 51.6, 25.4; IR $v$ (ATR) 1723, 1606, 1585, 1536, $755 \mathrm{~cm}^{-1}$; HRMS (EI) calcd for $\mathrm{C}_{21} \mathrm{H}_{18} \mathrm{~N}_{2} \mathrm{O}_{4}\left[\mathrm{M}^{+}\right]$ 362.1267 , found 362.1268 .

(E)-4-(2-Hydroxy-1-phenylvinyl)-3-nitro-2H-chromen-2-one (9) and 2-(3-nitro-2-oxo2H-chromen-4-yl)-2-phenylacetaldehyde (9a).

To a solution of compound $8(2.00 \mathrm{~g}, 5.52 \mathrm{mmol})$ in acetonitrile $(50 \mathrm{~mL})$ was added concentrated $\mathrm{HCl}$ ( 2 drops). The reaction was stirred at room temperature for $1 \mathrm{~h}$. After completion of the reaction, the solvent was concentrated in vacuo and the crude product was purified by column chromatography (Hex/EtOAc, 3:1) to obtain the title compounds as a light yellow solid (1.27 g, yield 74\%). mp 82-84 ${ }^{\circ} \mathrm{C} ;{ }^{1} \mathrm{H} \mathrm{NMR}\left(\mathrm{CDCl}_{3}, 400 \mathrm{MHz}\right)$ of $9 \delta 7.59(\mathrm{td}, J=8.0,1.6 \mathrm{~Hz}, 1 \mathrm{H}), 7.50(\mathrm{dd}, J=8.0,1.2 \mathrm{~Hz}, 1 \mathrm{H}), 7.41(\mathrm{~d}, J=8.0 \mathrm{~Hz}, 1 \mathrm{H})$, $7.38-7.34(\mathrm{~m}, 4 \mathrm{H}), 7.30-7.27(\mathrm{~m}, 1 \mathrm{H}), 7.22(\mathrm{td}, J=8.0,1.6 \mathrm{~Hz}, 1 \mathrm{H}), 7.14(\mathrm{bs}, 1 \mathrm{H})$; characteristic absorption peaks for $9 \mathrm{a} \delta 10.13(\mathrm{~s}, 1 \mathrm{H},-\mathrm{CHO}), 5.23(\mathrm{~s}, 1 \mathrm{H}$, benzylic $\mathrm{H}) ;{ }^{13} \mathrm{C}$ $\mathrm{NMR}\left(\mathrm{CDCl}_{3}, 150 \mathrm{MHz}\right)$ of $9 \delta 154.4,152.8,133.9,131.9,130.5,129.5,129.3,129.1$, $128.5,127.4,125.7,125.5,123.4,118.2,117.3$; IR $v$ (ATR) 3056, 1719, 1602, 1381, 785

$\mathrm{cm}^{-1}$; HRMS (EI) calcd for $\mathrm{C}_{17} \mathrm{H}_{11} \mathrm{NO}_{5}\left[\mathrm{M}^{+}\right] 309.0637$, found 309.0632 .

1-Phenylchromeno[3,4- $b]$ pyrrol-4(3H)-one (1).

To a solution of compound $9(155 \mathrm{mg}, 0.5 \mathrm{mmol})$ in $\mathrm{MeOH}(50 \mathrm{~mL})$ was added concentrated $\mathrm{HCl}$ ( 2 drops) and iron powder ( $137 \mathrm{mg}, 5$ equiv). The reaction was stirred at room temperature for $2 \mathrm{~h}$. After completion of the reaction, the solvent was concentrated in vacuo and the crude product was purified by column chromatography (Hex/EtOAc, 5:1) to obtain the title compound as a white solid (122 mg, yield 93\%). mp $250-251{ }^{\circ} \mathrm{C} ;{ }^{1} \mathrm{H}$ NMR $\left(\mathrm{CDCl}_{3}, 400 \mathrm{MHz}\right) \delta 10.29$ (bs, $\left.1 \mathrm{H}\right), 7.70$ (dd, $\left.J=8.0,0.8 \mathrm{~Hz}, 1 \mathrm{H}\right), 7.55-7.44$ (m, $6 \mathrm{H}), 7.38-7.34(\mathrm{~m}, 2 \mathrm{H}), 7.11(\mathrm{dd}, J=8.0,0.8 \mathrm{~Hz}, 1 \mathrm{H}) ;{ }^{13} \mathrm{C} \mathrm{NMR}\left(\mathrm{CDCl}_{3}, 100 \mathrm{MHz}\right) \delta$ 156.2 , 151.2, 134.2, 130.0, 128.7, 127.9, 127.7, 127.7, 126.0, 124.1, 123.6, 122.7, 118.4, 
117.5 (2C); IR v (ATR) 3226, 1706, 1391, 1106, $732 \mathrm{~cm}^{-1}$; HRMS (EI) calcd for $\mathrm{C}_{17} \mathrm{H}_{11} \mathrm{NO}_{2}$ $\left[\mathrm{M}^{+}\right]$261.0790, found 261.0787.

One-pot procedure for the preparations of 1-phenylchromeno[3,4-b]pyrrol-4(3H)-one (1). To a solution of 2-phenylacetaldehyde $(4,120 \mathrm{mg}, 1 \mathrm{mmol})$, pyrrolidine $(6,71 \mathrm{mg}, 1 \mathrm{mmol})$, and 4-chloro-3-nitrocoumarin $(\mathbf{3}, 225 \mathrm{mg}, 1 \mathrm{mmol})$ in dry dichloromethane $(10 \mathrm{~mL})$ was stirred at room temperature for $1 \mathrm{~h}$. The hydrochloric acid ( 2 drops in $30 \mathrm{~mL}$ of acetonitrile) was then added dropwise to the mixture and the resulting mixture was stirred at room temperature for $1 \mathrm{~h}$. To this mixture was further added iron powder ( $275 \mathrm{mg}, 5$ equiv) and stirred for $2 \mathrm{~h}$ at room temperature. After completion of the reaction, the solvent was concentrated in vacuo and the crude product was purified by column chromatography (Hex/EtOAc, 5:1) to obtain the title compound $\mathbf{1}$ as a white solid (203 mg) in 78\% yield for three steps.

3-Phenethyl-1-phenylchromeno[3,4-b]pyrrol-4(3H)-one (5).

To a solution of compound 1 (261 mg, $1 \mathrm{mmol})$ in DMF $(15 \mathrm{~mL})$ was added (2bromoethyl)benzene (10, $222 \mathrm{mg}, 1.2$ equiv) and $\mathrm{K}_{2} \mathrm{CO}_{3}$ (166 g, 1.2 equiv) at room temperature. The reaction was heated at $70{ }^{\circ} \mathrm{C}$ for $1 \mathrm{~h}$. After cooled down to room temperature, water $(30 \mathrm{~mL})$ was added to the mixture. The product was extracted with DCM $(3 \times 50 \mathrm{~mL})$ and the combined organic layer was dried over $\mathrm{Na}_{2} \mathrm{SO}_{4}$, and concentrated in vacuo. The crude product was purified by column chromatography (Hex/EtOAc, 4:1) to obtain the title compound as a white solid (358 mg, yield 98\%). mp $125-126{ }^{\circ} \mathrm{C} ;{ }^{1} \mathrm{H}$ NMR $\left(\mathrm{CDCl}_{3}, 400 \mathrm{MHz}\right) \delta 7.61(\mathrm{~d}, J=8.0 \mathrm{~Hz}, 1 \mathrm{H}), 7.46-7.37(\mathrm{~m}, 6 \mathrm{H})$, $7.33-7.24(\mathrm{~m}, 4 \mathrm{H}), 7.13(\mathrm{~d}, J=6.8 \mathrm{~Hz}, 2 \mathrm{H}), 7.05(\mathrm{t}, J=6.8 \mathrm{~Hz}, 1 \mathrm{H}), 6.75(\mathrm{~s}, 1 \mathrm{H}), 4.70(\mathrm{t}$, $J=6.8 \mathrm{~Hz}, 2 \mathrm{H}), 3.19(\mathrm{t}, J=6.8 \mathrm{~Hz}, 2 \mathrm{H}) ;{ }^{13} \mathrm{C} \mathrm{NMR}\left(\mathrm{CDCl}_{3}, 100 \mathrm{MHz}\right) \delta 155.3,151.5$, 138.0, 134.4, 132.1, 129.9, 129.1, 128.8, 128.7, 127.74, 127.69, 127.0, 126.6, 123.9, 123.5, 120.5, 118.6, 117.4, 116.1, 51.1, 38.3; IR v (ATR) 1707, 1388, 1054, 745, $696 \mathrm{~cm}^{-1}$; HRMS (EI) calcd for $\mathrm{C}_{25} \mathrm{H}_{19} \mathrm{NO}_{2}\left[\mathrm{M}^{+}\right]$365.1416, found 365.1421.

2-Bromo-1-phenylchromeno[3,4-b]pyrrol-4(3H)-one (11).

To a solution of compound $\mathbf{1}(200 \mathrm{mg}, 0.77 \mathrm{mmol})$ in anhydrous THF $(15 \mathrm{~mL})$ was added $\mathrm{N}$-bromosuccinimide (177 $\mathrm{mg}, 1.3$ equiv) at $0{ }^{\circ} \mathrm{C}$. The resulting mixture was allowed to warm to room temperature and stirred for $2 \mathrm{~h}$, then diluted with $\mathrm{H}_{2} \mathrm{O}(10 \mathrm{~mL})$ and extracted with DCM $(4 \times 20 \mathrm{~mL})$. The combined organic phases were washed with $\mathrm{H}_{2} \mathrm{O}(1 \times 30 \mathrm{~mL})$ and brine $(1 \times 20 \mathrm{~mL})$ before being dried $\left(\mathrm{Na}_{2} \mathrm{SO}_{4}\right)$, filtered, and concentrated in vacuo. The crude product was purified by column chromatography (Hex/EtOAc, 4:1) to obtain the title compound as a white solid (252 mg, yield 97\%); mp 290-292 ${ }^{\circ} \mathrm{C} ;{ }^{1} \mathrm{H} \mathrm{NMR}\left(\mathrm{CDCl}_{3}\right.$, $400 \mathrm{MHz}) \delta 10.90(\mathrm{bs}, 1 \mathrm{H}), 7.56-7.50(\mathrm{~m}, 3 \mathrm{H}), 7.48-7.43$ (m, 3H), 7.40 (dd, $J=8.0,1.6$ $\mathrm{Hz}, 1 \mathrm{H}), 7.35(\mathrm{td}, J=8.0,1.6 \mathrm{~Hz}, 1 \mathrm{H}), 7.06(\mathrm{td}, J=8.0,1.2 \mathrm{~Hz}, 1 \mathrm{H}) ;{ }^{13} \mathrm{C} \mathrm{NMR}\left(\mathrm{CDCl}_{3}\right.$, $100 \mathrm{MHz}) \delta 155.1,151.5,132.7,130.8,129.0,128.7,128.4,127.5,124.4,123.6,121.8$, 
117.8 (2C), 117.5, 113.8; IR v (ATR) 3257, 1723, 1536, 787, $695 \mathrm{~cm}^{-1}$; HRMS (EI) calcd for $\mathrm{C}_{17} \mathrm{H}_{10} \mathrm{BrNO}_{2}\left[\mathrm{M}^{+}\right]$338.9895, found 338.9899 .

1,2-Diphenylchromeno[3,4-b]pyrrol-4(3H)-one (12).

To a solution of compound $11(170 \mathrm{mg}, 0.5 \mathrm{mmol})$ in dioxane $(15 \mathrm{~mL})$ was added phenylboronic acid (91 mg, 1.5 equiv), 2-dicyclohexylphosphino-2',6'-dimethoxybiphenyl (4.1 mg, $2 \mathrm{~mol} \%), \mathrm{Pd}(\mathrm{OAc})_{2}\left(1.2 \mathrm{mg}, 1 \mathrm{~mol} \%\right.$ ), and finely ground $\mathrm{K}_{2} \mathrm{CO}_{3}(104$ $\mathrm{mg}, 1.5$ equiv) at room temperature. The resulting mixture was then refluxed for $1 \mathrm{~h}$. After completion of the reaction, water $(10 \mathrm{~mL})$ was added to the cooled mixture and the product was extracted with DCM (4 x $20 \mathrm{~mL})$. The combined organic phases were washed with $\mathrm{H}_{2} \mathrm{O}(1 \times 30 \mathrm{~mL})$ and brine $(1 \times 20 \mathrm{~mL})$ before being dried $\left(\mathrm{Na}_{2} \mathrm{SO}_{4}\right)$, filtered, and concentrated in vacuo. The crude product was purified by column chromatography (Hex/EtOAc, 3:1) to obtain the title compound as a white solid (157 mg, yield 93\%). mp 273-274 ${ }^{\circ} \mathrm{C}$ (lit. ${ }^{1} 273-274{ }^{\circ} \mathrm{C}$ ); ${ }^{1} \mathrm{H}$ NMR (DMSO-d $\left.6,400 \mathrm{MHz}\right) \delta 9.51$ (bs, 1H), 7.51-7.40 (m, 3H), 7.37-7.27 (m, 10H), $7.15(\mathrm{~d}, J=8.0 \mathrm{~Hz}, 1 \mathrm{H})$.

4-Hydroxy-6, 7-dimethoxy-3-nitrocoumarin (16).

To a stirred suspension of 4-hydroxy-6,7-dimethoxycoumarin $(15,500 \mathrm{mg}, 2.25 \mathrm{mmol})$ in $\mathrm{CHCl}_{3}(30 \mathrm{~mL})$ was carefully added fuming $\mathrm{HNO}_{3}(\sim 0.5 \mathrm{~mL})$ at $0{ }^{\circ} \mathrm{C}$ until the solution turned into deep brown. The solution was allowed to stir at room temperature for $10 \mathrm{~min}$, and then the solvent was removed in vacuo. The crude reaction mixture was suspended in $30 \% \mathrm{HCl}$ solution $(50 \mathrm{~mL})$ and was stirred at room temperature for $20 \mathrm{~min}$ as the precipitate formed. The precipitate was filtered, washed with water, and dried in vacuo to afford compound 16 as a brown solid (525 mg; yield 87\%); mp $\geq 220{ }^{\circ} \mathrm{C}$ (charred) (lit. ${ }^{2} \geq 220{ }^{\circ} \mathrm{C}$ (charred)); ${ }^{1} \mathrm{H}$ NMR $\left(\mathrm{CD}_{3} \mathrm{OD}, 400 \mathrm{MHz}\right) \delta 7.40$ (s, 1H), 6.71 (s, 1H), 3.89 (s, 3H), 3.83 (s, $3 \mathrm{H})$.

4-Chloro-6,7-dimethoxy-3-nitrocoumarin (13).

To the cooled solution of 4-hydroxy-6,7-dimethoxy-3-nitrocoumarin (16, 250 mg) in DMF $(10 \mathrm{~mL})$ was added dropwise $\mathrm{POCl}_{3}(3 \mathrm{~mL})$ at room temperature. The resulting mixture was heated at $80{ }^{\circ} \mathrm{C}$ for $30 \mathrm{~min}$. After cooled down to room temperature, the mixture was poured into ice-cooled water and the formed precipitate was filtered, washed with hexane, dried in vacuo, and recrystallized in DCM to give a brown solid (245 mg; yield 93\%); mp 217-219 ${ }^{\circ} \mathrm{C}$ (lit. $\left.{ }^{2} 273-274{ }^{\circ} \mathrm{C}\right) ;{ }^{1} \mathrm{H}$ NMR $\left(\mathrm{CDCl}_{3}, 400 \mathrm{MHz}\right) \delta 7.27$ (s, 1H), $6.91(\mathrm{~s}, 1 \mathrm{H})$, $4.02(\mathrm{~s}, 3 \mathrm{H}), 4.00(\mathrm{~s}, 3 \mathrm{H})$.

9-Chloro-2,3,6,7-tetrahydro-1H,5H,11H-pyrano[2,3-f]pyrido[3,2,1-ij]quinolin-11-one (18).

To a solution of compound $17(515 \mathrm{mg}, 2 \mathrm{mmol})$ in acetonitrile $(15 \mathrm{~mL})$ was slowly added $\mathrm{POCl}_{3}(1 \mathrm{~mL})$ at $0{ }^{\circ} \mathrm{C}$ for $30 \mathrm{~min}$. The resulting mixture was allowed to heat at $70{ }^{\circ} \mathrm{C}$ for 4 
h. After cooled down to room temperature, the mixture was quenched by ice water $(10 \mathrm{~mL})$ and extracted with DCM $(4 \times 20 \mathrm{~mL})$. The combined organic phases were washed with $\mathrm{H}_{2} \mathrm{O}(1 \times 30 \mathrm{~mL})$ and brine $(1 \times 20 \mathrm{~mL})$ before being dried $\left(\mathrm{Na}_{2} \mathrm{SO}_{4}\right)$, filtered, and concentrated in vacuo. The crude product was purified by column chromatography (Hex/EtOAc, 7:3) to obtain the title compound as an orange solid (503 mg, yield 91\%); mp $158-159{ }^{\circ} \mathrm{C} ;{ }^{1} \mathrm{H}$ NMR $\left(\mathrm{CDCl}_{3}, 400 \mathrm{MHz}\right) \delta 7.21(\mathrm{~s}, 1 \mathrm{H}), 6.14(\mathrm{~s}, 1 \mathrm{H}), 7.24(\mathrm{dd}, J=8.0$, $1.2 \mathrm{~Hz}, 1 \mathrm{H}), 7.21(\mathrm{~d}, J=8.8 \mathrm{~Hz}, 2 \mathrm{H}), 3.31-3.26(\mathrm{~m}, 4 \mathrm{H}), 2.87(\mathrm{t}, J=6.4 \mathrm{~Hz}, 2 \mathrm{H}), 2.79$ (t, $J=6.4 \mathrm{~Hz}, 2 \mathrm{H}), 2.00-1.94(\mathrm{~m}, 4 \mathrm{H}) ;{ }^{13} \mathrm{C} \mathrm{NMR}\left(\mathrm{CDCl}_{3}, 100 \mathrm{MHz}\right) \delta 161.0,150.6,150.2$, 146.9, 122.4, 112.7, 107.0, 106.6, 106.2, 50.0, 49.5, 27.6, 21.3, 20.4 (2C); IR v (ATR) 3078, 2947, 2854, 1707, $1352 \mathrm{~cm}^{-1}$; HRMS (EI) calcd for $\mathrm{C}_{15} \mathrm{H}_{14} \mathrm{ClNO}_{2}\left[\mathrm{M}^{+}\right]$275.0713, found 275.0715 .

9-Chloro-10-nitro-2,3,6,7-tetrahydro-1H,5H,11H-pyrano[2,3-f]pyrido[3,2,1-ij]quinolin11-one (14).

To a solution of compound $17(200 \mathrm{mg}, 0.7 \mathrm{mmol})$ in acetic acid $(3 \mathrm{~mL})$ at $0{ }^{\circ} \mathrm{C}$ was slowly added $\mathrm{HNO}_{3}(0.5 \mathrm{~mL})$ until the solution turned into deep brown. The solution was allowed to stir further at room temperature for $5 \mathrm{~min}$. After completion of the reaction, the resulting mixture was quenched by ice water $(30 \mathrm{~mL})$ and extracted with DCM $(4 \times 30 \mathrm{~mL})$. The combined organic layers were washed with $\mathrm{H}_{2} \mathrm{O}(1 \times 30 \mathrm{~mL})$ and brine $(1 \times 30 \mathrm{~mL})$ before being dried $\left(\mathrm{Na}_{2} \mathrm{SO}_{4}\right)$, filtered, and concentrated in vacuo. The crude product was purified by column chromatography (Hex/EtOAc, $3: 1)$ to obtain the title compound as a brown solid (169 mg, yield 73\%). mp $228-229{ }^{\circ} \mathrm{C} ;{ }^{1} \mathrm{H} \mathrm{NMR}\left(\mathrm{CDCl}_{3}, 400 \mathrm{MHz}\right) \delta 7.39(\mathrm{~d}, J=8.8 \mathrm{~Hz}$, $2 \mathrm{H}), 7.29(\mathrm{td}, J=8.0,1.2 \mathrm{~Hz}, 1 \mathrm{H}), 7.24(\mathrm{dd}, J=8.0,1.2 \mathrm{~Hz}, 1 \mathrm{H}), 7.21(\mathrm{~d}, J=8.8 \mathrm{~Hz}, 2 \mathrm{H})$, 6.89 (td, $J=8.0,1.2 \mathrm{~Hz}, 1 \mathrm{H}), 6.76(\mathrm{~d}, J=8.0 \mathrm{~Hz}, 1 \mathrm{H}), 5.97(\mathrm{~s}, 1 \mathrm{H}), 3.00$ (s, $3 \mathrm{H}), 2.43$ (s, $3 \mathrm{H}) ;{ }^{13} \mathrm{C} \mathrm{NMR}\left(\mathrm{CDCl}_{3}, 100 \mathrm{MHz}\right) \delta 153.9,150.0,149.4,143.1,129.5,124.4,121.1,106.0$, 104.3, 50.4, 49.9, 27.7, 20.9, 20.2, 20.0; IR v (ATR) 3425, 2938, 2842, 1718, $1305 \mathrm{~cm}^{-1}$; HRMS (EI) calcd for $\mathrm{C}_{15} \mathrm{H}_{13} \mathrm{ClN}_{2} \mathrm{O}_{4}\left[\mathrm{M}^{+}\right]$320.0564, found 320.0560 .

1-(3,4-Dimethoxyphenyl)-7,8-dimethoxychromeno[3,4-b]pyrrol-4(3H)-one (21).

To a solution of 2-(3,4-dimethoxyphenyl)acetaldehyde (20,180 $\mathrm{mg}, 1 \mathrm{mmol})$, pyrrolidine $(\mathbf{6}, 71 \mathrm{mg}, 1 \mathrm{mmol})$, and compound $\mathbf{1 3}(286 \mathrm{mg}, 1 \mathrm{mmol})$ in dry dichloromethane $(10 \mathrm{~mL})$ was stirred at room temperature for $1 \mathrm{~h}$. The hydrochloric acid solution (4 drops of conc. $\mathrm{HCl}$ in $30 \mathrm{~mL}$ of acetonitrile) was then added dropwise to the mixture and the resulting mixture was stirred at room temperature for $1 \mathrm{~h}$. To this mixture was further added iron powder ( $275 \mathrm{mg}, 5$ equiv) and stirred for $2 \mathrm{~h}$ at room temperature. After completion of the reaction, the solvent was concentrated in vacuo and the crude product was purified by column chromatography (DCM/EtOAc, 4:1) to obtain the title compound as a light yellow solid (207 mg, yield 54\%). mp 230-231 ${ }^{\circ} \mathrm{C} ;{ }^{1} \mathrm{H} \mathrm{NMR}\left(\mathrm{CDCl}_{3}, 400 \mathrm{MHz}\right) \delta 10.30(\mathrm{bs}, 1 \mathrm{H})$, $7.23(\mathrm{~d}, J=7.6 \mathrm{~Hz}, 1 \mathrm{H}), 7.16(\mathrm{~s}, 1 \mathrm{H}), 7.09(\mathrm{~s}, 1 \mathrm{H}), 7.06(\mathrm{~d}, J=7.6 \mathrm{~Hz}, 1 \mathrm{H}), 6.95(\mathrm{~s}, 1 \mathrm{H})$, $6.75(\mathrm{~s}, 1 \mathrm{H}), 3.98(\mathrm{~s}, 3 \mathrm{H}), 3.95(\mathrm{~s}, 3 \mathrm{H}), 3.92(\mathrm{~s}, 3 \mathrm{H}), 3.85(\mathrm{~s}, 3 \mathrm{H}) ;{ }^{13} \mathrm{C} \mathrm{NMR}\left(\mathrm{CDCl}_{3}, 100\right.$ 
MHz) $\delta$ 159.7, 149.1, 148.6, 148.2, 146.4, 145.3, 126.7, 124.0, 123.5, 121.7, 115.9, 111.7, 109.8, 109.3, 108.9, 106.0, 101.7, 56.8, 56.6, 56.1 (2C); IR $v$ (ATR) 1505, 1253, 1203, $1173,1019,748 \mathrm{~cm}^{-1}$; HRMS (EI) calcd for $\mathrm{C}_{21} \mathrm{H}_{19} \mathrm{NO}_{6}\left[\mathrm{M}^{+}\right]$381.1212, found 381.1205.

Hexamethyl ningalin B (23).

To a solution of compound 21 (381 mg) in DMF (5 mL) was added 4-(2-bromoethyl)-1,2dimethoxybenzene (22, $294 \mathrm{mg}, 1.2$ equiv) and $\mathrm{K}_{2} \mathrm{CO}_{3}$ (166 mg, 1.2 equiv) at room temperature. The reaction was heated at $70{ }^{\circ} \mathrm{C}$ for $1 \mathrm{~h}$. After cooled down to room temperature, water $(20 \mathrm{~mL})$ was added to the mixture. The product was extracted with $\operatorname{DCM}(3 \times 30 \mathrm{~mL})$ and the combined organic layer was dried over $\mathrm{Na}_{2} \mathrm{SO}_{4}$ and concentrated in vacuo. The crude product was purified by column chromatography (DCM/EtOAc, 9:1) to obtain the title compound as a white solid (527 mg, yield 97\%); mp $185-186{ }^{\circ} \mathrm{C}$ (lit. ${ }^{3}$ $\left.186-187^{\circ} \mathrm{C}\right),{ }^{1} \mathrm{H} \mathrm{NMR}\left(\mathrm{CDCl}_{3}, 400 \mathrm{MHz}\right) \delta 7.09(\mathrm{~s}, 1 \mathrm{H}), 6.97-6.94(\mathrm{~m}, 3 \mathrm{H}), 6.90(\mathrm{~d}, J=$ $1.2 \mathrm{~Hz}, 1 \mathrm{H}), 6.80(\mathrm{~d}, J=8.0 \mathrm{~Hz}, 1 \mathrm{H}), 6.74(\mathrm{~s}, 1 \mathrm{H}), 6.71(\mathrm{~d}, J=8.0 \mathrm{~Hz}, 1 \mathrm{H}), 6.58(\mathrm{~d}, J=$ $1.6 \mathrm{~Hz}, 1 \mathrm{H}), 4.62(\mathrm{t}, J=6.8 \mathrm{~Hz}, 2 \mathrm{H}), 3.96(\mathrm{~s}, 3 \mathrm{H}), 3.93(\mathrm{~s}, 3 \mathrm{H}), 3.91(\mathrm{~s}, 3 \mathrm{H}), 3.83(\mathrm{~s}, 3 \mathrm{H})$, 3.77 (s, 3H), 3.65 (s, 3H), 3.19 (t, $J=6.8 \mathrm{~Hz}, 2 \mathrm{H})$.

Ningalin B (19).

Following the procedure detailed by Boger et al. ${ }^{3}$ To a solution of compound $\mathbf{2 3}(17.0 \mathrm{mg})$ in $\mathrm{CH}_{2} \mathrm{Cl}_{2}(3 \mathrm{~mL})$ under $\mathrm{Ar}$ at $-78{ }^{\circ} \mathrm{C}$ was treated with $\mathrm{BBr}_{3}(0.5 \mathrm{~mL}$ of $1 \mathrm{M}$ in hexanes), and the mixture was allowed to warm to $25^{\circ} \mathrm{C}$ in a period of $24 \mathrm{~h}$. Following dilution with $\mathrm{MeOH}(0.50 \mathrm{~mL})$, the solvent was removed by a stream of $\mathrm{N}_{2}$ to afford compound 19 (14.1 mg, yield 98\%). mp 301-303 ${ }^{\circ} \mathrm{C}$ (lit. $303{ }^{\circ} \mathrm{C}$ ); ${ }^{1} \mathrm{H}$ NMR $\left(20 \% \mathrm{CD}_{3} \mathrm{OD} / \mathrm{DMSO}-d_{6}, 400\right.$ MHz) $\delta 7.17(\mathrm{~s}, 1 \mathrm{H}), 7.07(\mathrm{~s}, 1 \mathrm{H}), 6.80(\mathrm{~d}, J=8.0 \mathrm{~Hz}, 1 \mathrm{H}), 6.77(\mathrm{~d}, J=2.0 \mathrm{~Hz}, 1 \mathrm{H}), 6.75$ (s, 1H), $6.63(\mathrm{dd}, J=8.0,2.0 \mathrm{~Hz}, 1 \mathrm{H}), 6.59(\mathrm{~d}, J=8.0 \mathrm{~Hz}, 1 \mathrm{H}), 6.43$ (dd, $J=8.0,2.0 \mathrm{~Hz}$, $1 \mathrm{H}), 4.49$ (t, $J=7.2 \mathrm{~Hz}, 2 \mathrm{H}), 2.87$ (t, $J=7.2 \mathrm{~Hz}, 2 \mathrm{H})$.

1-Phenyl-7,8,11,12-tetrahydro-6H,10H-pyrido[3,2,1-ij]pyrrolo[3',2':4,5]pyrano[2,3f]quinolin-4(3H)-one (25).

To a solution of 2-phenylacetaldehyde $(4,120 \mathrm{mg}, 1 \mathrm{mmol})$, pyrrolidine $(6,71 \mathrm{mg}, 1 \mathrm{mmol})$, and compound $14(321 \mathrm{mg}, 1 \mathrm{mmol})$ in dry dichloromethane $(10 \mathrm{~mL})$ was stirred at room temperature for $1 \mathrm{~h}$. The hydrochloric acid solution (2 drops of conc. $\mathrm{HCl}$ in $30 \mathrm{~mL}$ of acetonitrile) was then added dropwise to the mixture and the resulting mixture was stirred at room temperature for $1 \mathrm{~h}$. To this mixture was further added iron powder $(275 \mathrm{mg}, 5$ equiv) and stirred for $2 \mathrm{~h}$ at room temperature. After completion of the reaction, the solvent was concentrated in vacuo and the crude product was purified by column chromatography (Hex/EtOAc, 4:1) to obtain the title compound as a light yellow solid (290 mg, yield $81 \%$ ). mp 278-280 ${ }^{\circ} \mathrm{C} ;{ }^{1} \mathrm{H}$ NMR $\left(\mathrm{CDCl}_{3}, 400 \mathrm{MHz}\right) \delta 9.60$ (bs, $\left.1 \mathrm{H}\right), 7.52(\mathrm{~d}, J=7.2 \mathrm{~Hz}, 2 \mathrm{H})$, $7.45(\mathrm{~d}, J=7.2 \mathrm{~Hz}, 2 \mathrm{H}), 7.40(\mathrm{~d}, J=7.2 \mathrm{~Hz}, 1 \mathrm{H}), 7.21(\mathrm{~d}, J=2.4 \mathrm{~Hz}, 1 \mathrm{H}), 7.12(\mathrm{~s}, 1 \mathrm{H})$, $3.18-3.14(\mathrm{~m}, 4 \mathrm{H}), 2.98(\mathrm{t}, J=6.4 \mathrm{~Hz}, 2 \mathrm{H}), 2.59$ (t, $J=6.4 \mathrm{~Hz}, 2 \mathrm{H}$ ), 2.01 (quintet, $J=6.4$ 
$\mathrm{Hz}, 2 \mathrm{H}$ ), 1.92 (quintet, $J=6.4 \mathrm{~Hz}, 2 \mathrm{H}$ ); ${ }^{13} \mathrm{C}$ NMR (DMSO- $\left.d_{6}, 100 \mathrm{MHz}\right) \delta 154.8,147.9$, $142.6,134.8,129.4,128.7,128.5,127.1,125.9,120.0,119.9,117.2,115.0,107.6,106.1$, 49.2, 48.7, 27.2, 21.3, 20.9, 20.7; IR v (ATR) 3211, 3048, 2935, 2842, $1687 \mathrm{~cm}^{-1}$; HRMS (EI) calcd for $\mathrm{C}_{23} \mathrm{H}_{20} \mathrm{~N}_{2} \mathrm{O}_{2}\left[\mathrm{M}^{+}\right] 356.1525$, found 356.1528 .

2-Bromo-1-phenyl-7,8,11,12-tetrahydro-6H,10H-pyrido[3,2,1ij]pyrrolo[3',2':4,5]pyrano[2,3-f]quinolin-4(3H)-one (26).

To a solution of compound 25 (178 $\mathrm{mg}, 0.5 \mathrm{mmol})$ in anhydrous THF (15 mL) was added $\mathrm{N}$-bromosuccinimide (116 mg, $1.3 \mathrm{equiv}$ ) at $0{ }^{\circ} \mathrm{C}$. The resulting mixture was allowed to warm to room temperature and stirred for $30 \mathrm{~min}$. The mixture was further diluted with $\mathrm{H}_{2} \mathrm{O}(10 \mathrm{~mL})$ and extracted with DCM $(4 \times 20 \mathrm{~mL})$. The combined organic layers were washed with $\mathrm{H}_{2} \mathrm{O}(1 \times 30 \mathrm{~mL})$ and brine $(1 \times 20 \mathrm{~mL})$ before being dried $\left(\mathrm{Na}_{2} \mathrm{SO}_{4}\right)$, filtered, and concentrated in vacuo. The crude product was purified by column chromatography (Hex/EtOAc, 5:1) to obtain the title compound as a light yellow solid (205 mg, yield 94\%). mp 267-268 ${ }^{\circ} \mathrm{C} ;{ }^{1} \mathrm{H}$ NMR $\left(\mathrm{CDCl}_{3}, 400 \mathrm{MHz}\right) \delta 9.78$ (bs, 1H), 7.54-7.51 (m, 2H), 7.48$7.44(\mathrm{~m}, 2 \mathrm{H}) 7.42-7.40(\mathrm{~m}, 1 \mathrm{H}), 7.24(\mathrm{~s}, 1 \mathrm{H}), 3.41-3.37(\mathrm{~m}, 4 \mathrm{H}), 2.84(\mathrm{t}, J=6.4 \mathrm{~Hz}, 2 \mathrm{H})$, $2.80(\mathrm{t}, J=6.4 \mathrm{~Hz}, 2 \mathrm{H}), 2.02-1.94(\mathrm{~m}, 4 \mathrm{H}) ;{ }^{13} \mathrm{C} \mathrm{NMR}\left(\mathrm{CDCl}_{3}, 100 \mathrm{MHz}\right) \delta 155.6,150.2$, $147.5,140.7,139.3,132.3,128.5,126.9,125.7(2 \mathrm{C}), 124.9,119.6,110.5,109.2$, 105.7, 50.1, 49.7, 27.6, 21.1, 20.4, 20.3; IR v (ATR) 3307, 2969, 2829, 1714, $1470 \mathrm{~cm}^{-1}$; HRMS (EI) calcd for $\mathrm{C}_{23} \mathrm{H}_{19} \mathrm{BrN}_{2} \mathrm{O}_{2}\left[\mathrm{M}^{+}\right]$434.0630, found 434.0628.

1,2-Diphenyl-7,8,11,12-tetrahydro-6H,10H-pyrido[3,2,1-ij]pyrrolo[3',2':4,5]pyrano[2,3$f$ ]quinolin-4(3H)-one (24).

To a solution of compound $26(217 \mathrm{mg}, 0.5 \mathrm{mmol})$ in dioxane $(15 \mathrm{~mL})$ was added phenylboronic acid (91 mg, 1.5 equiv), 2-dicyclohexylphosphino-2',6'-dimethoxybiphenyl (4.1 mg, $2 \mathrm{~mol} \%), \mathrm{Pd}(\mathrm{OAc})_{2}\left(1.2 \mathrm{mg}, 1 \mathrm{~mol} \%\right.$ ), and finely ground $\mathrm{K}_{2} \mathrm{CO}_{3}(104$ $\mathrm{mg}, 1.5$ equiv) at room temperature. The mixture was refluxed for $1 \mathrm{~h}$. After completion of the reaction, the resulting mixture was added $\mathrm{H}_{2} \mathrm{O}(10 \mathrm{~mL})$ and extracted with DCM $(4 \mathrm{x}$ $20 \mathrm{~mL})$. The combined organic layers were washed with $\mathrm{H}_{2} \mathrm{O}(1 \times 30 \mathrm{~mL})$ and brine $(1 \mathrm{x}$ $20 \mathrm{~mL}$ ) before being dried $\left(\mathrm{Na}_{2} \mathrm{SO}_{4}\right)$, filtered, and concentrated in vacuo. The crude product was purified by column chromatography (Hex/EtOAc, 4:1) to obtain the title compound as a light yellow solid (199 mg, yield 92\%). mp 210-211 ${ }^{\circ} \mathrm{C} ;{ }^{1} \mathrm{H} \mathrm{NMR}\left(\mathrm{CDCl}_{3}, 400 \mathrm{MHz}\right) \delta$ 9.32 (bs, 1H), 7.37-7.35 (m, 3H), 7.26-7.25 (m, 2H), 7.18-7.14 (m, 2H), 7.10 (d, $J=6.8$ $\mathrm{Hz}, 1 \mathrm{H}), 6.96(\mathrm{~s}, 1 \mathrm{H}), 6.82(\mathrm{~d}, J=8.0 \mathrm{~Hz}, 2 \mathrm{H}), 3.32-3.27(\mathrm{~m}, 4 \mathrm{H}), 2.83-2.80(\mathrm{~m}, 4 \mathrm{H})$, 2.01-1.95 (m, 4H); ${ }^{13} \mathrm{C} \mathrm{NMR}\left(\mathrm{CDCl}_{3}, 100 \mathrm{MHz}\right) \delta 162.2,151.5,147.9,137.6,133.9,129.3$, $128.8,128.4,128.2,127.7,126.6,126.3,125.3,124.9,124.1,123.3,117.6,108.2,105.5$, 50.1, 49.7, 27.5, 21.6, 20.7, 20.3; IR v (ATR) 3200, 3042, 2937, 2840, $1703 \mathrm{~cm}^{-1}$; HRMS (EI) calcd for $\mathrm{C}_{29} \mathrm{H}_{24} \mathrm{~N}_{2} \mathrm{O}_{2}\left[\mathrm{M}^{+}\right]$432.1838, found 432.1840 . 


\section{References}

1. Mei, R.; Zhang, S.-K.; Ackermann, L. Synlett 2017, 28, 1715-1718.

2. Manjappa. B. K.; Lin, J. M.; Yang, D. Y. J. Org. Chem. 2017, 82, 7648-7656.

3. Boger, D. L.; Soenen, D. R.; Boyce, C. W.; Hedrick, M. P.; Jin, Q. J. Org. Chem. 2000, 65, 2479-2483.

4. Steglich, W.; Peschko, C.; Winklhofer, C.; Terpin, A. Synthesis 2006, 18, 3048-3057. 


\section{Copies of $1 \mathrm{H}$ and $13 \mathrm{C}$ NMR spectra of synthesized compounds}

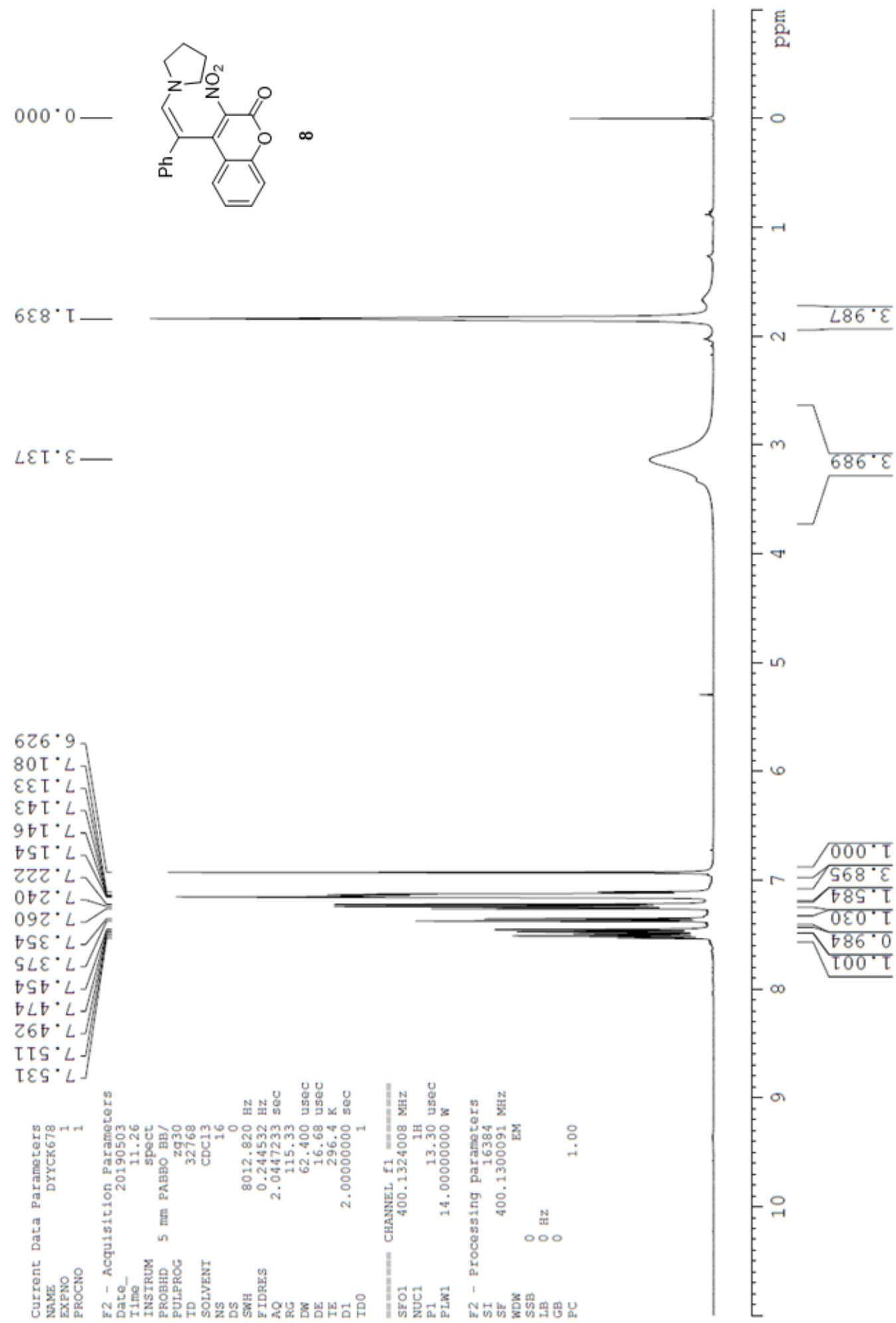




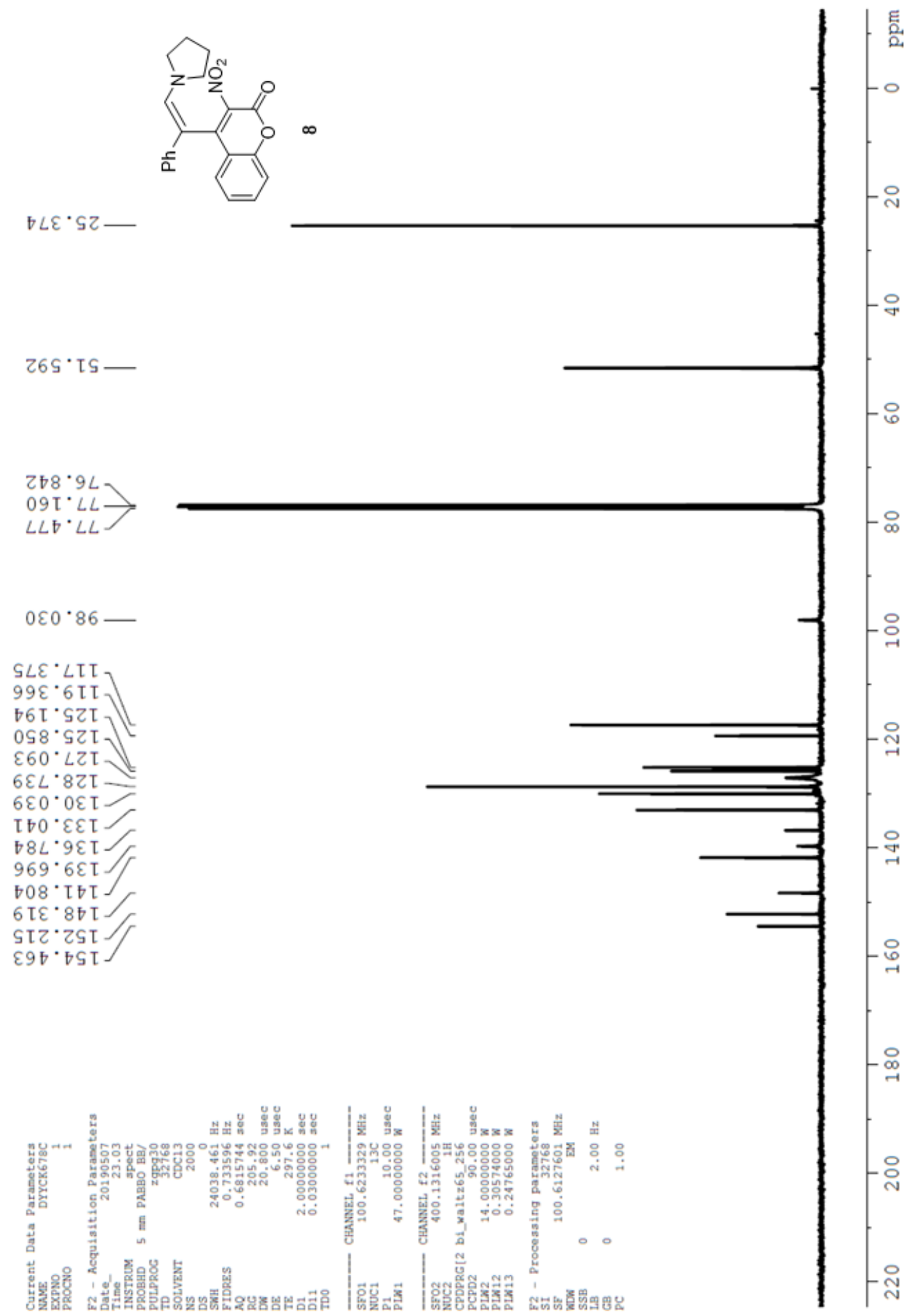




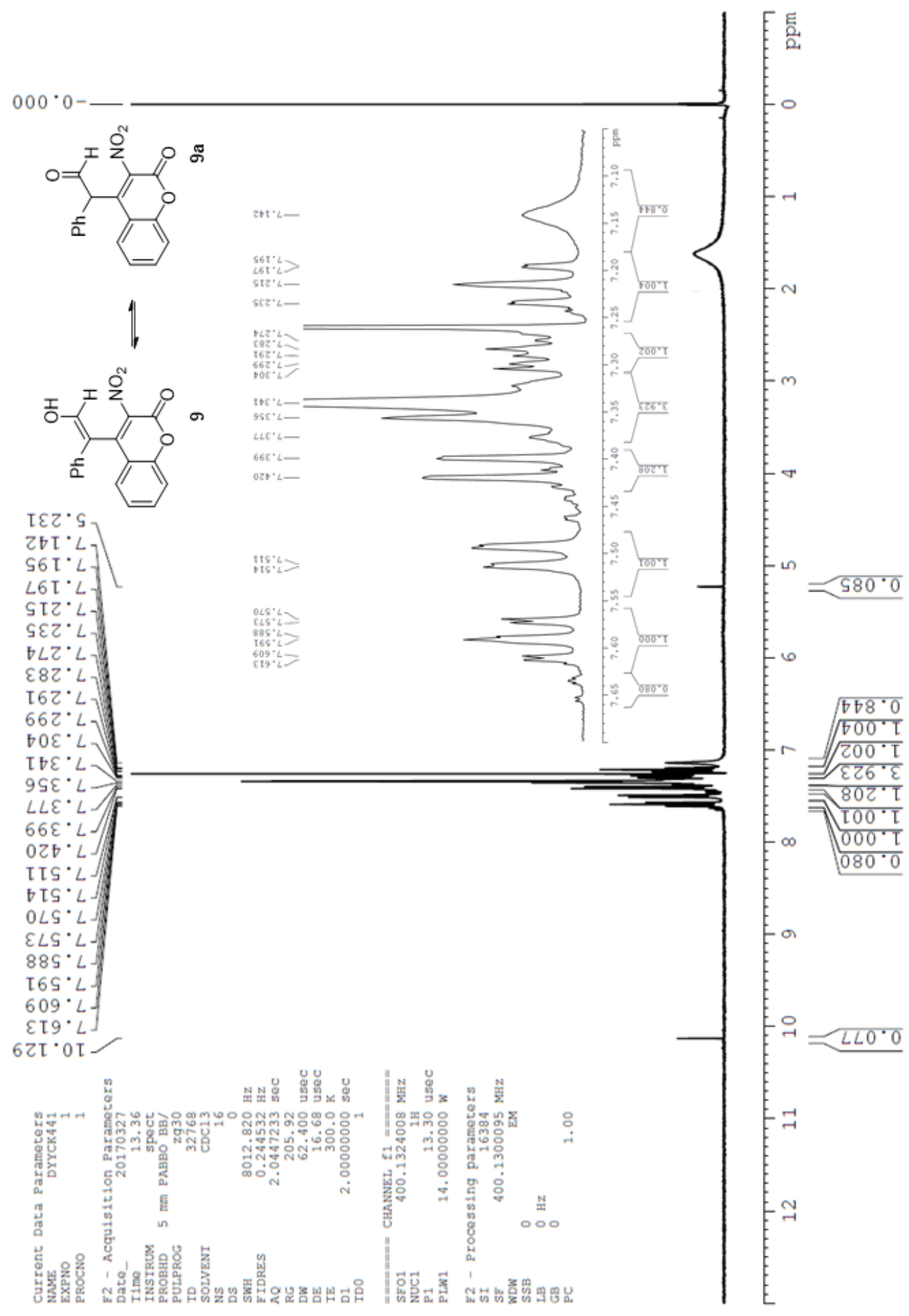




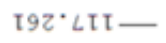

$98 \mathrm{~T} \cdot 8 \mathrm{Tt}-$

$\downarrow Z \bullet \cdot \varepsilon Z \mathrm{I}-$

$\mathrm{L} \angle V^{\circ} \cdot \mathrm{SZI}$
$\mathrm{SL9} \cdot \mathrm{SZT}$

$8 Z b^{\circ} \mathrm{LZT}$

$6 \mathrm{IS}^{\circ} \cdot 8 \mathrm{ZI}$
$0 \mathrm{~S} 0^{\circ} 6 \mathrm{ZI}$

$8 \mathrm{I} \varepsilon \cdot 6 \mathrm{TI}$

$\angle 6 \mathrm{~b} \cdot 62 \mathrm{~T}$

$66 b^{\circ} 0 \varepsilon \mathrm{I}$

$688^{\circ}$ โย โ -

$9 ७ 6^{\circ} \varepsilon \varepsilon \mathrm{I}-$
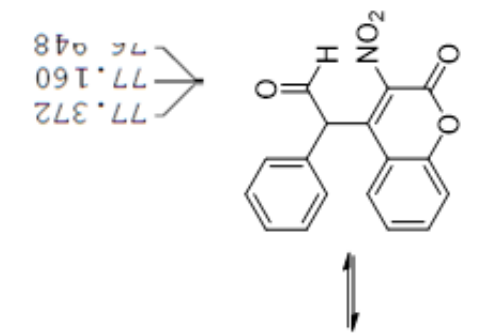

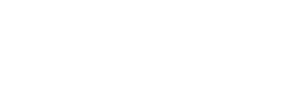

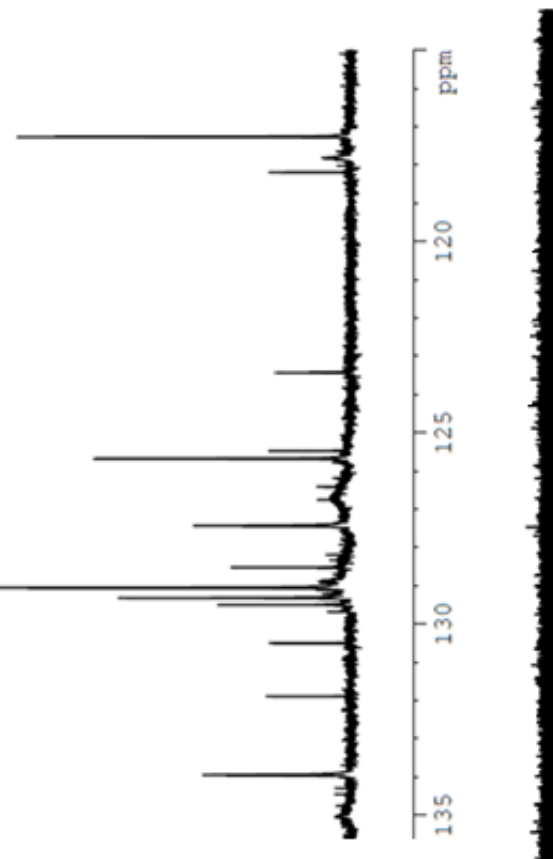

్ㅡㅇ

E。

=잉

韭웅

=일

이앙

야을

๓

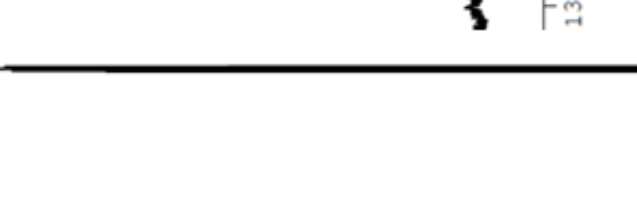

,
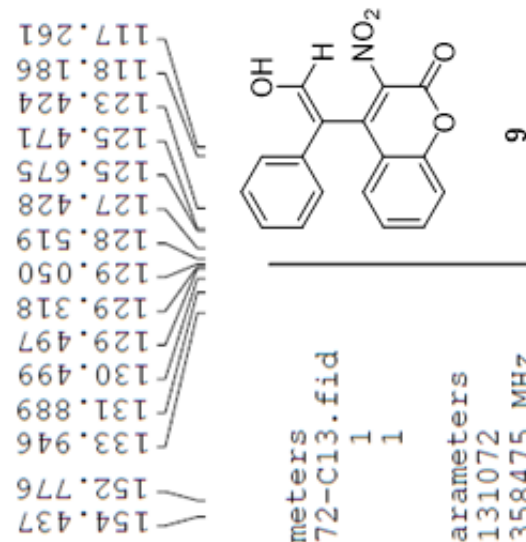

$\sigma$

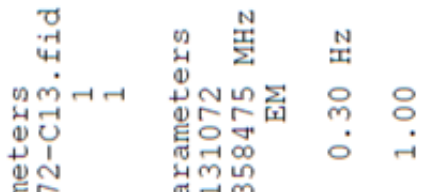

致

薄

ए马ं

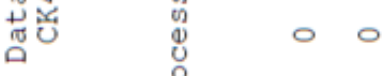

पे

떤을을

盗品

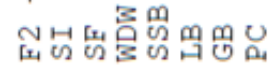

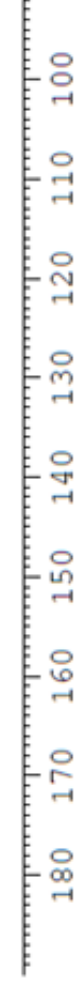




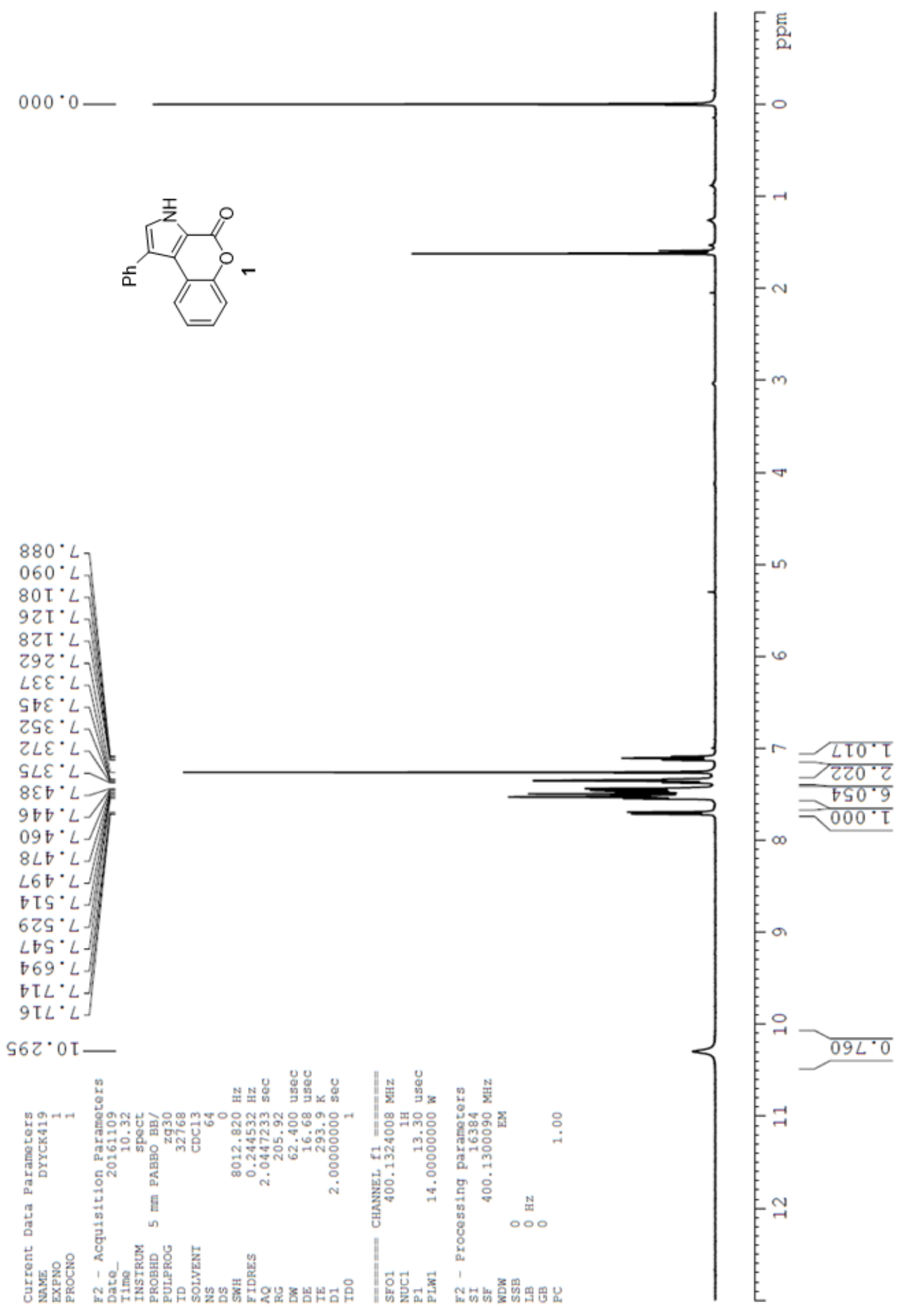




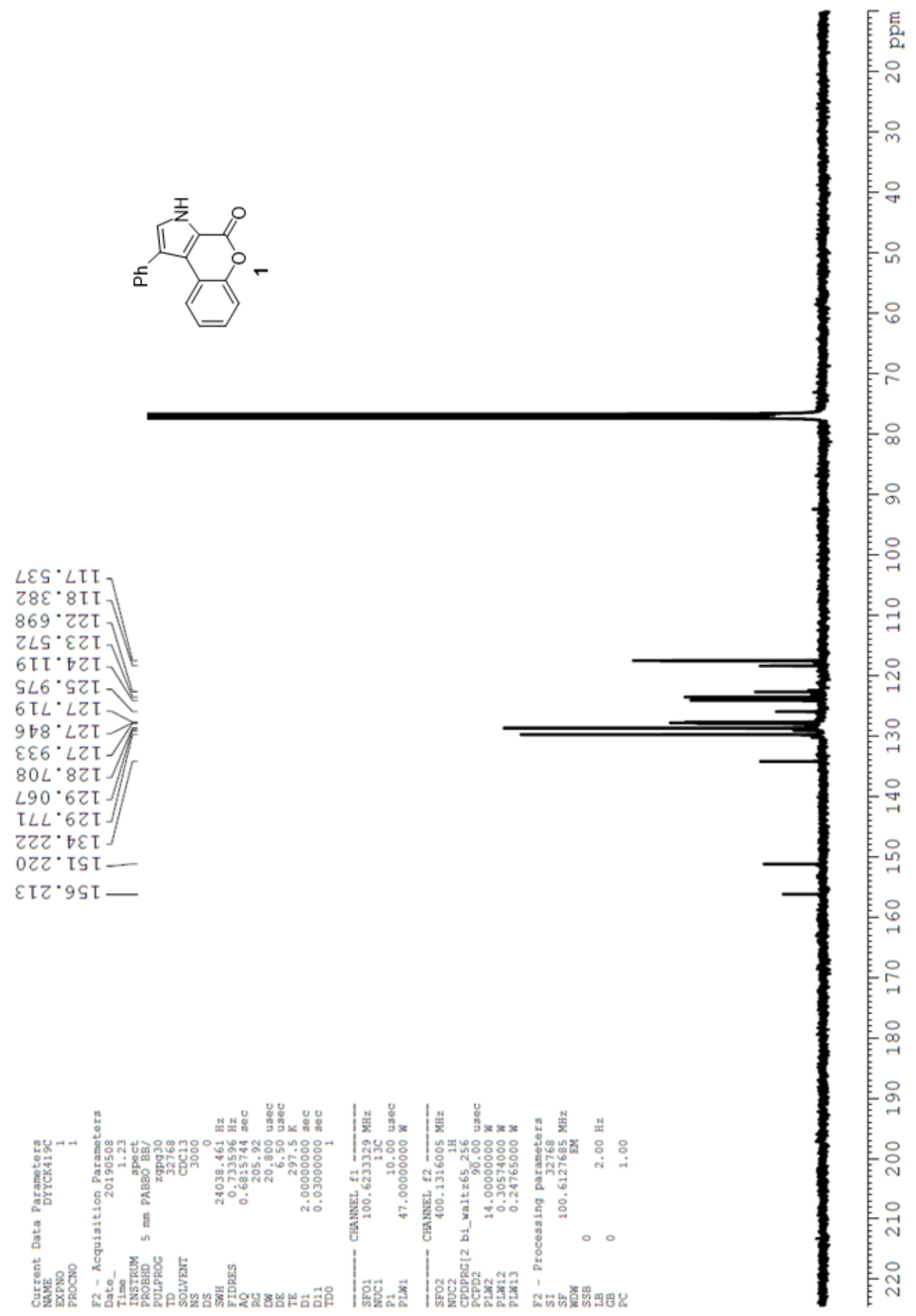




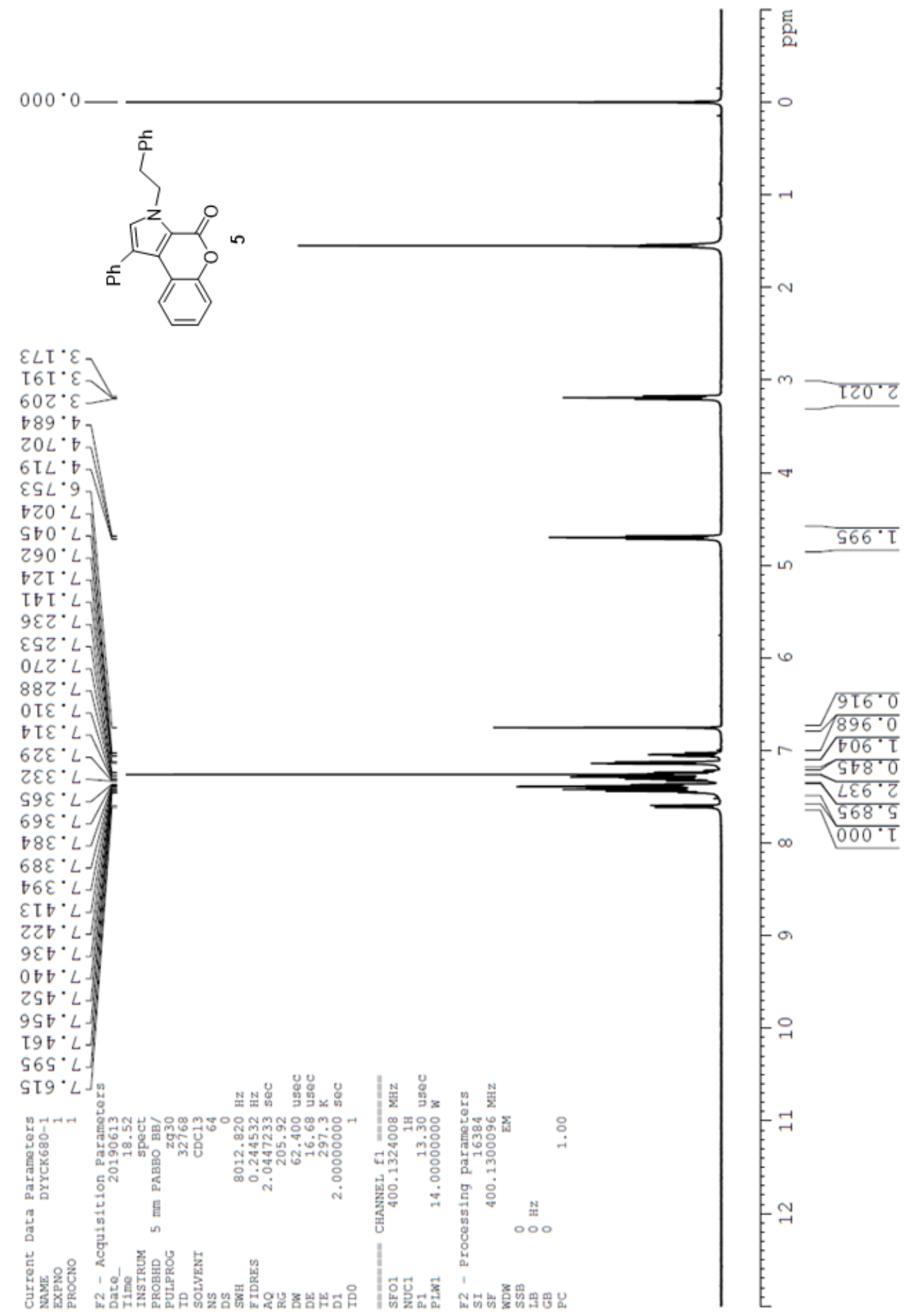




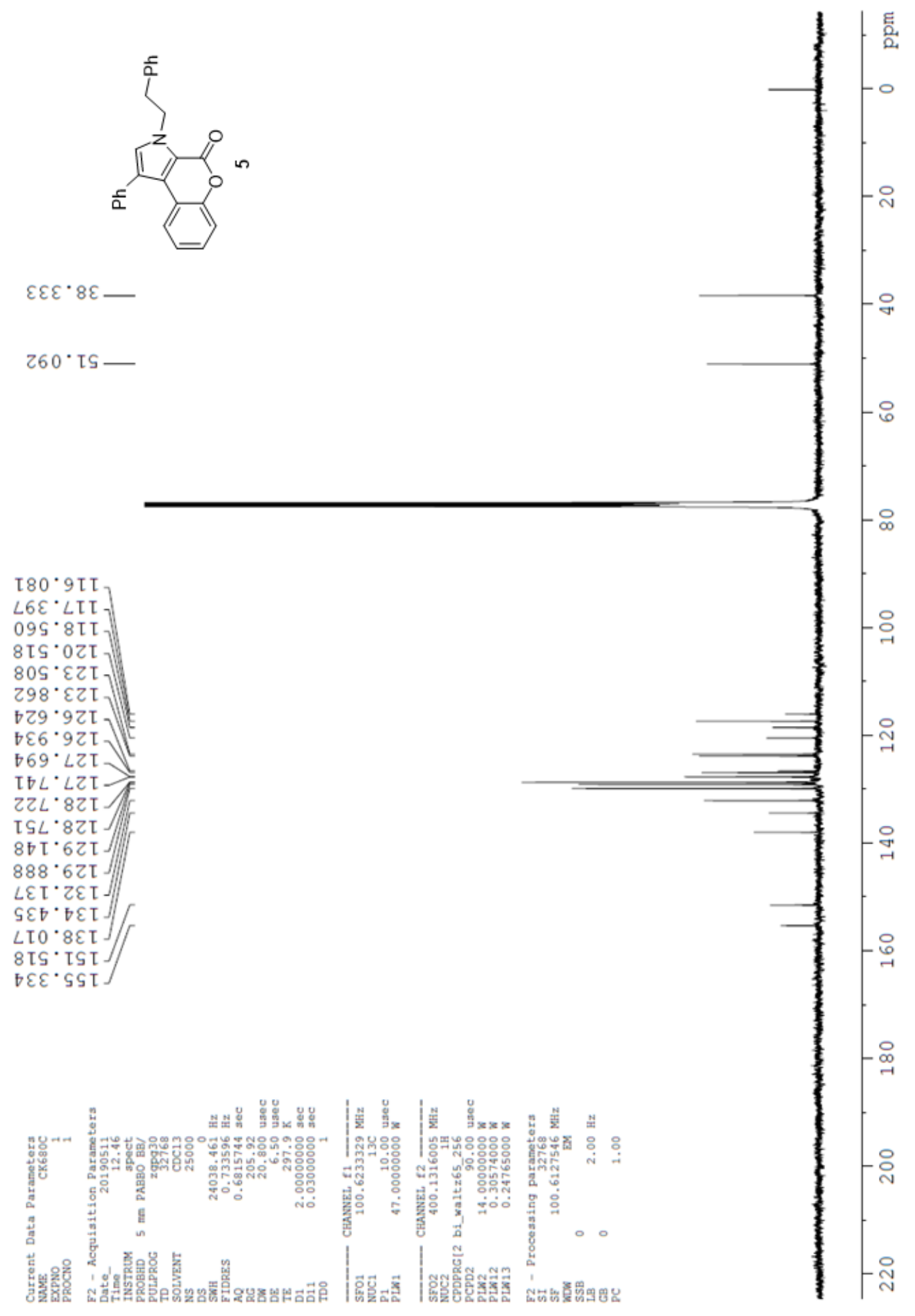




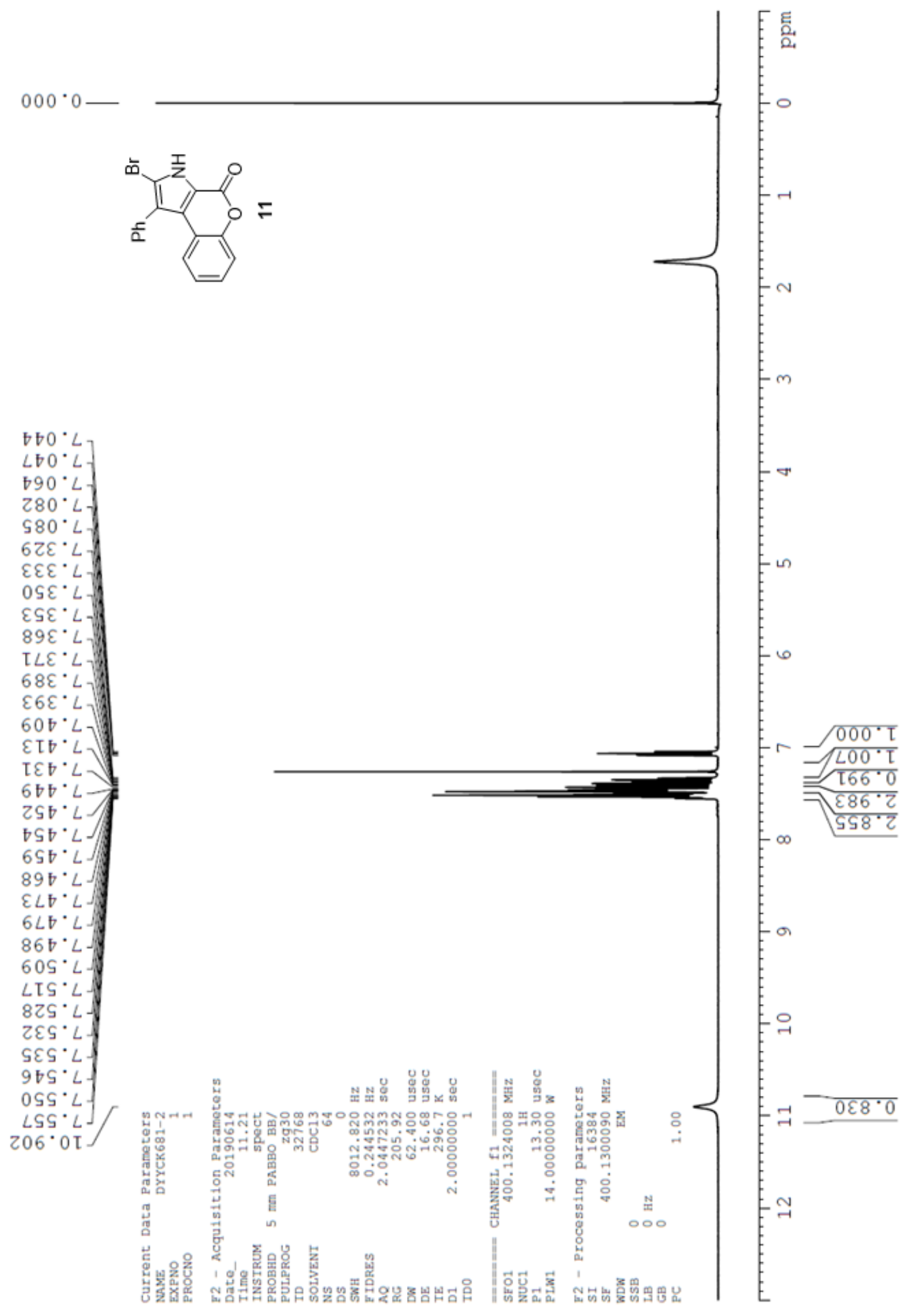




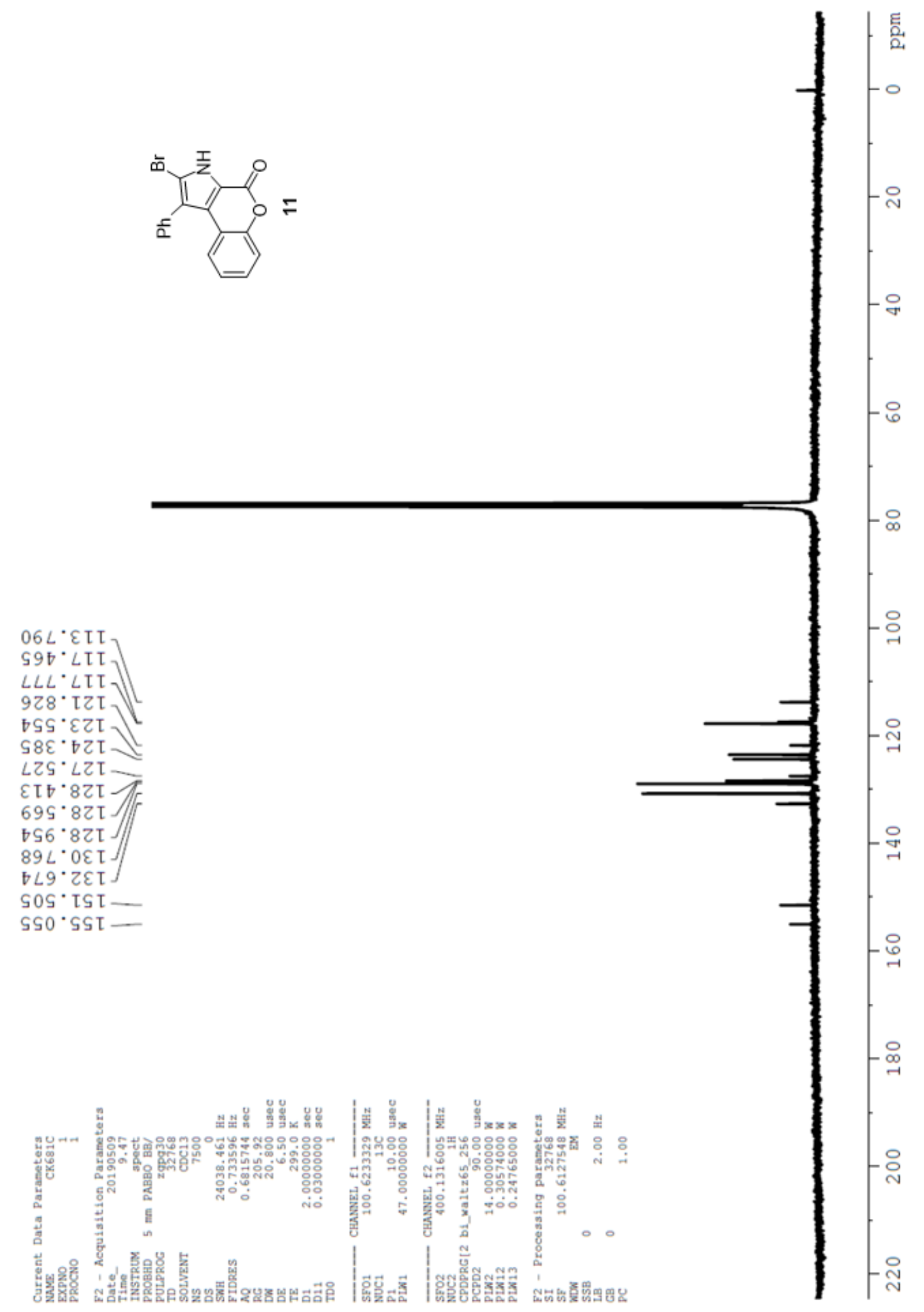




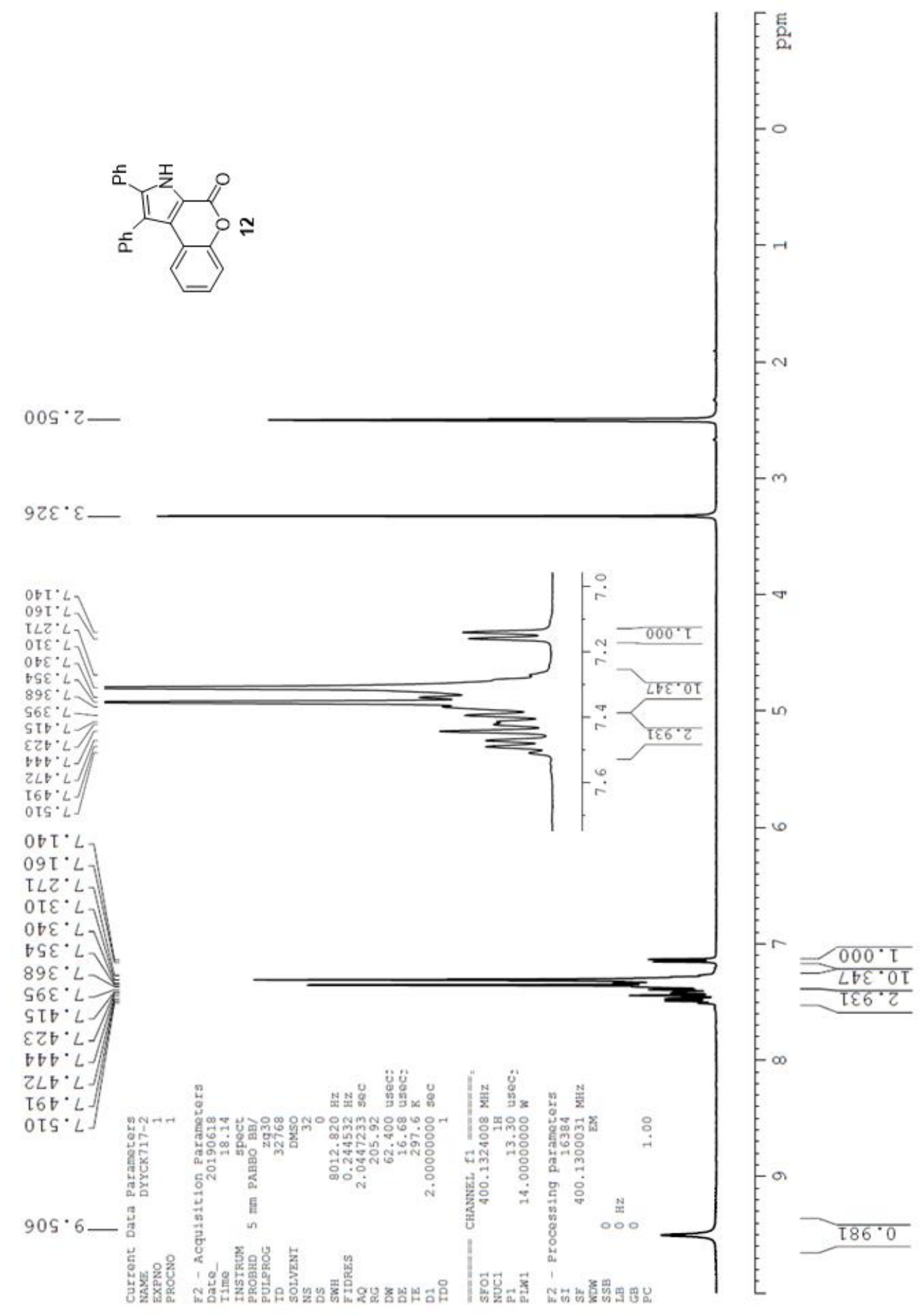




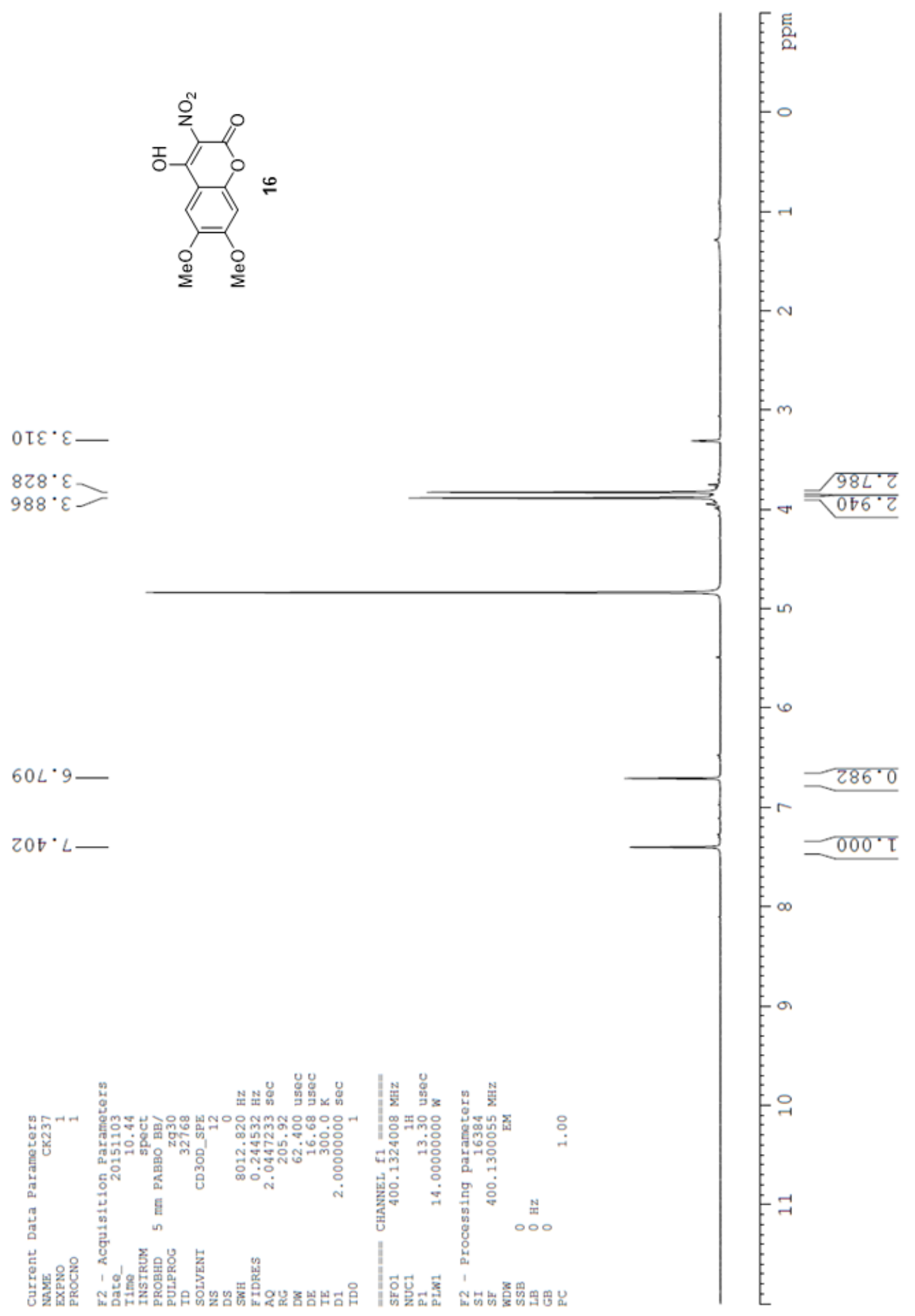




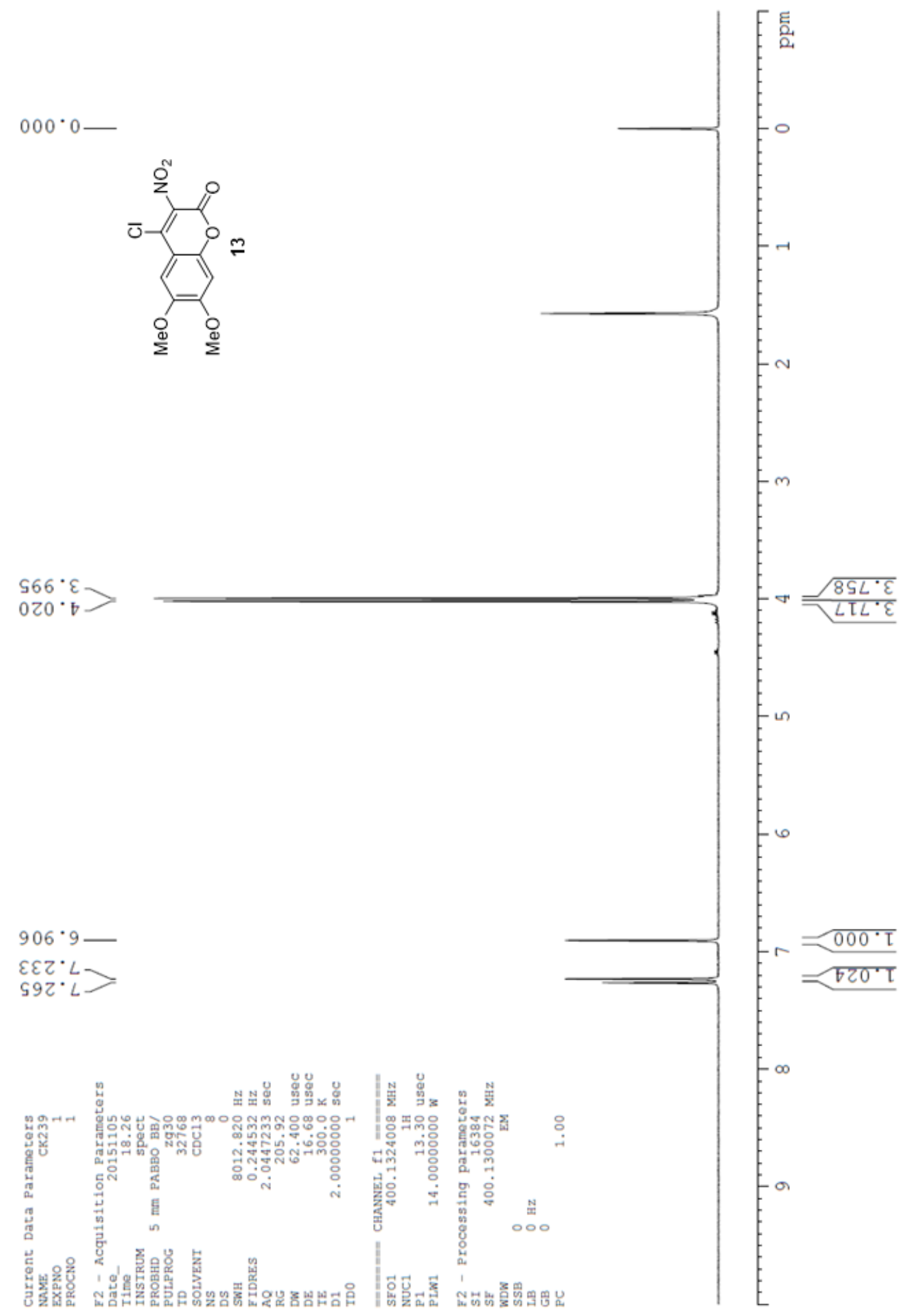




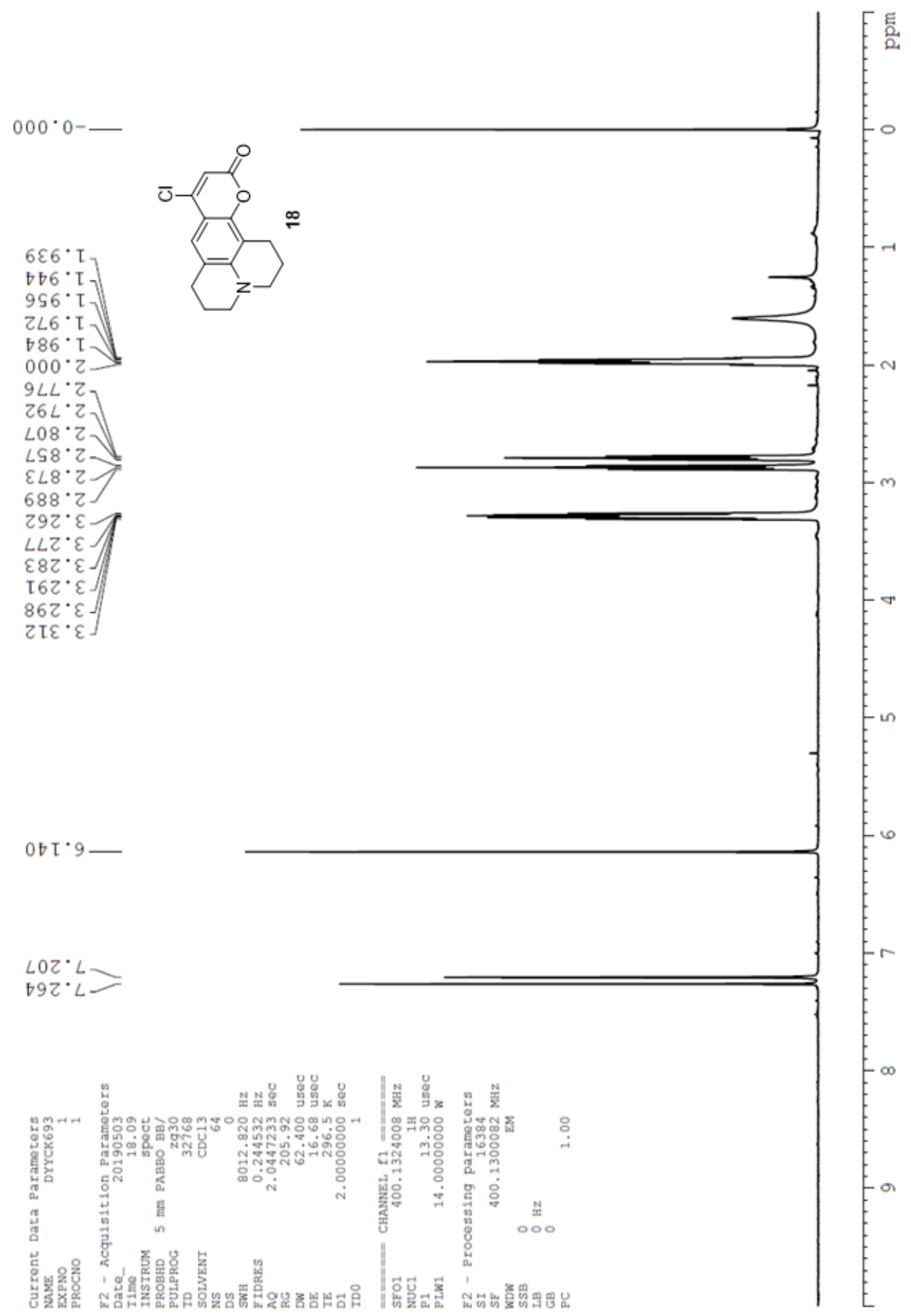




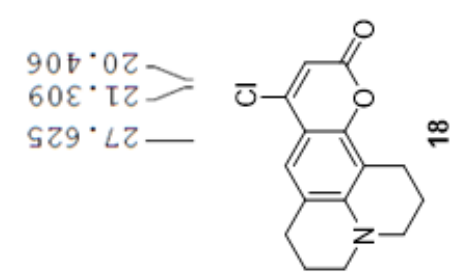

$6 \varepsilon s \cdot 6 b$
$886 \cdot 6 b$

โZZ $\cdot 90$ T

LT9.90T

$9 \varepsilon 0^{\circ}$ LOI

$8 Z L^{\circ} 8 \mathrm{IT}$

$\varepsilon 6 \varepsilon^{\circ} \mathrm{ZZT}$

$068^{\circ} 96 \mathrm{~L}-$

$\varepsilon L T^{\circ} 0 \mathrm{ST}>$

$\angle L 6^{\circ} 09 \mathrm{I}$

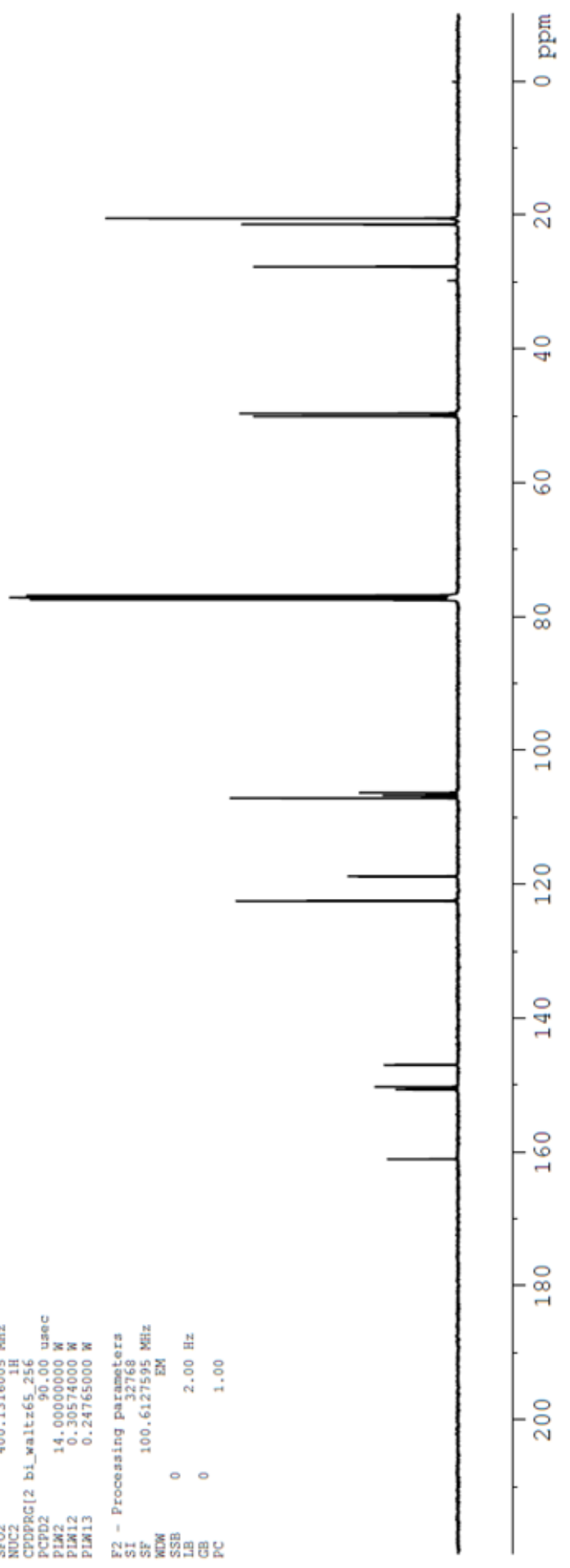




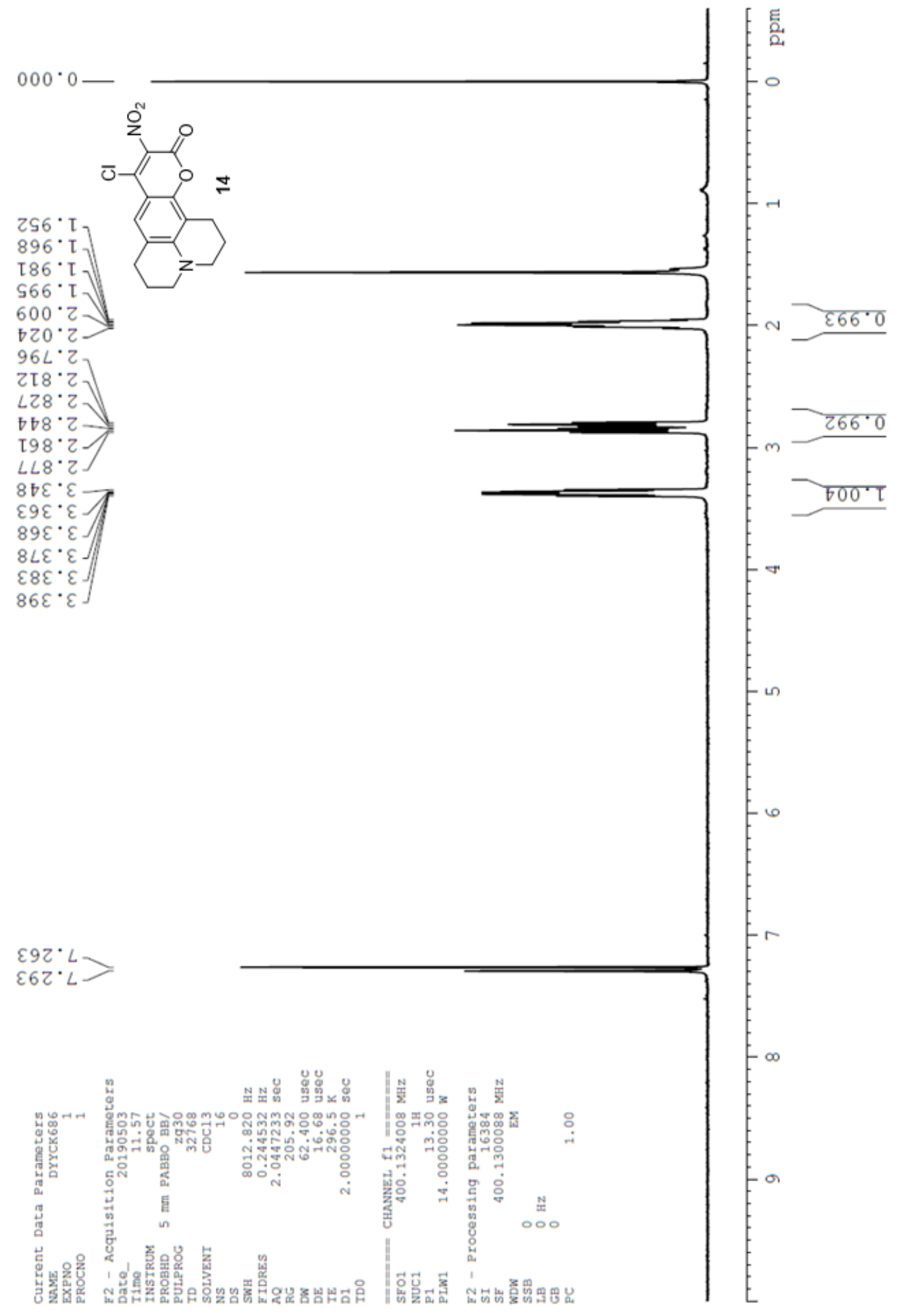




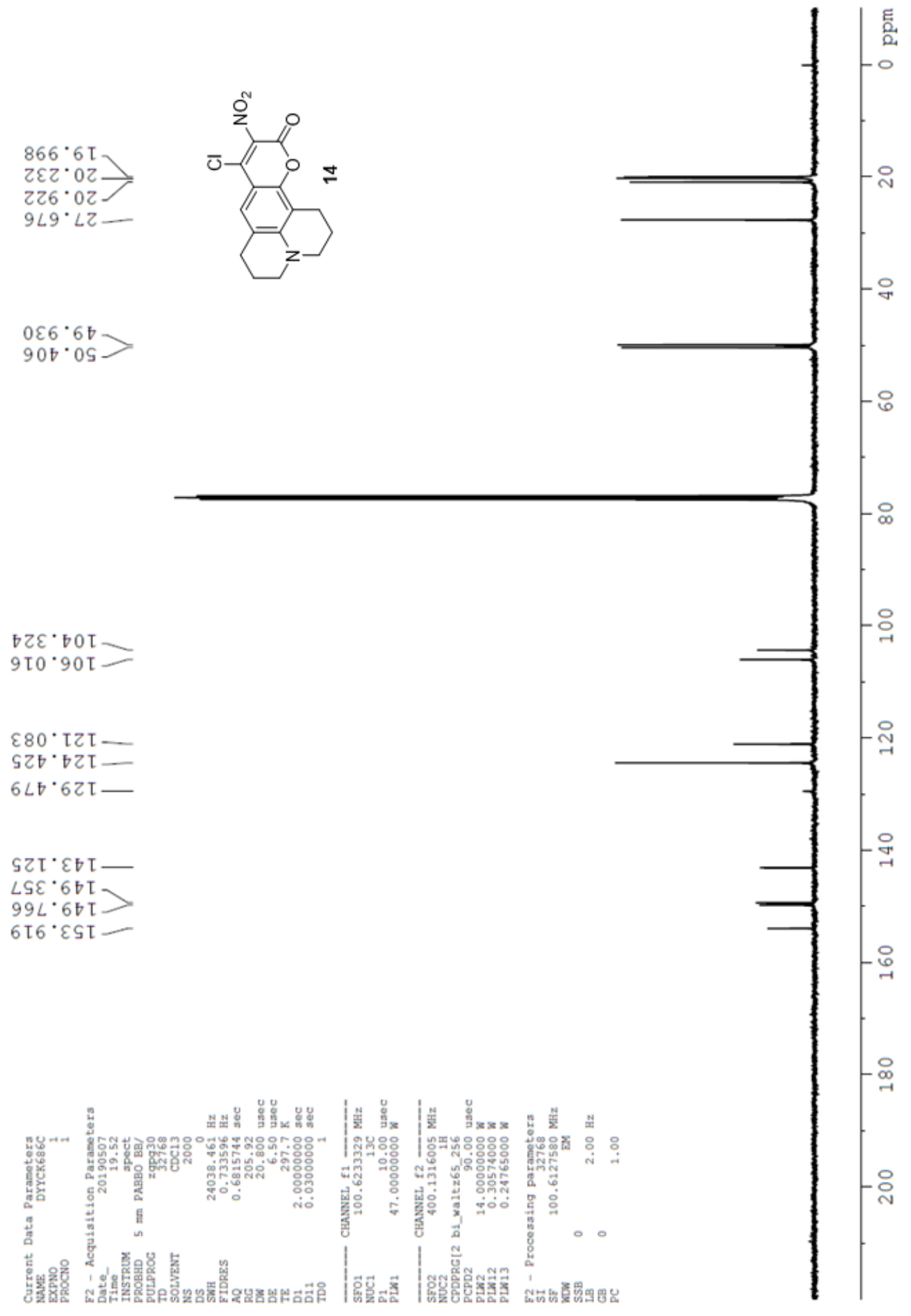




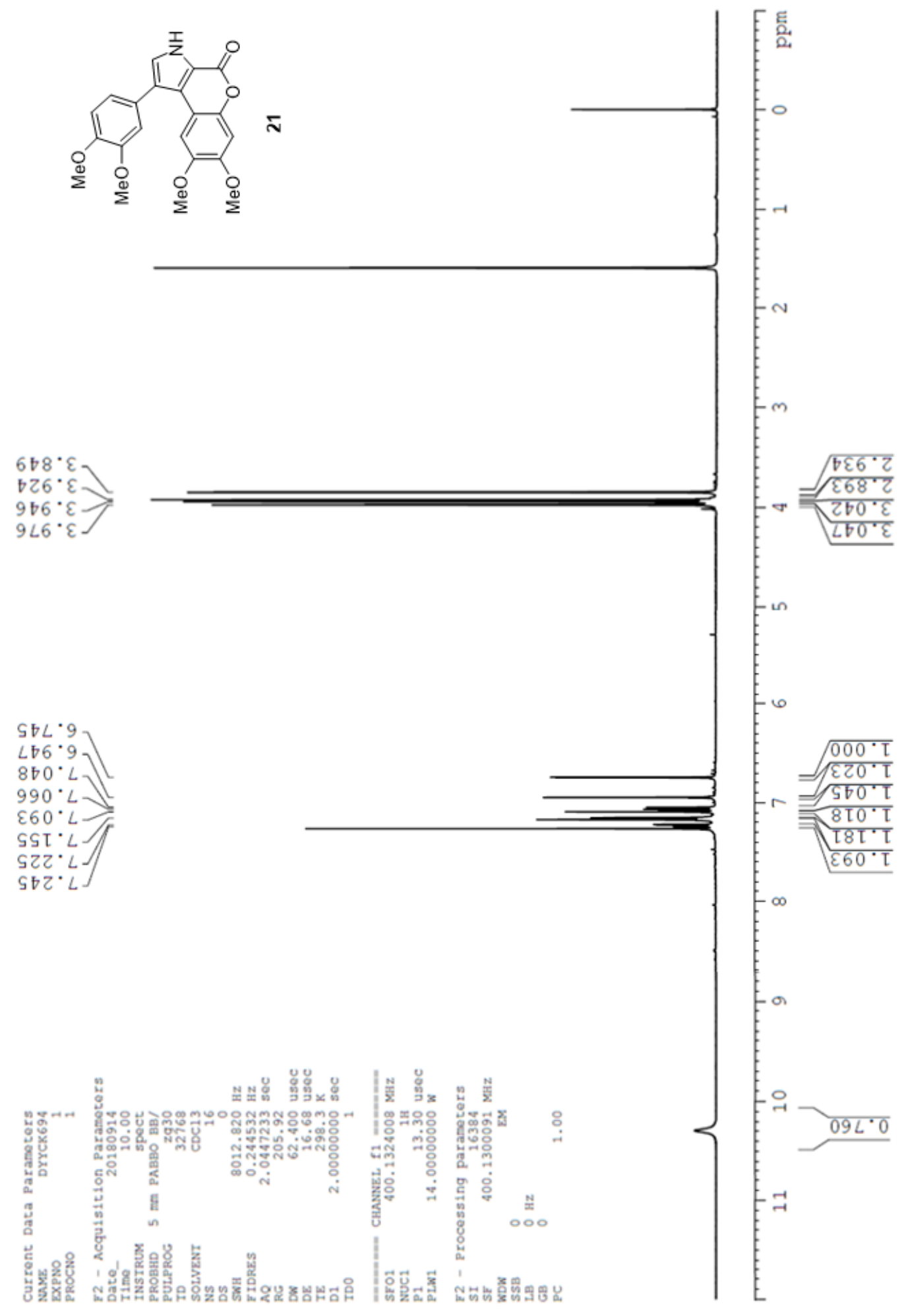



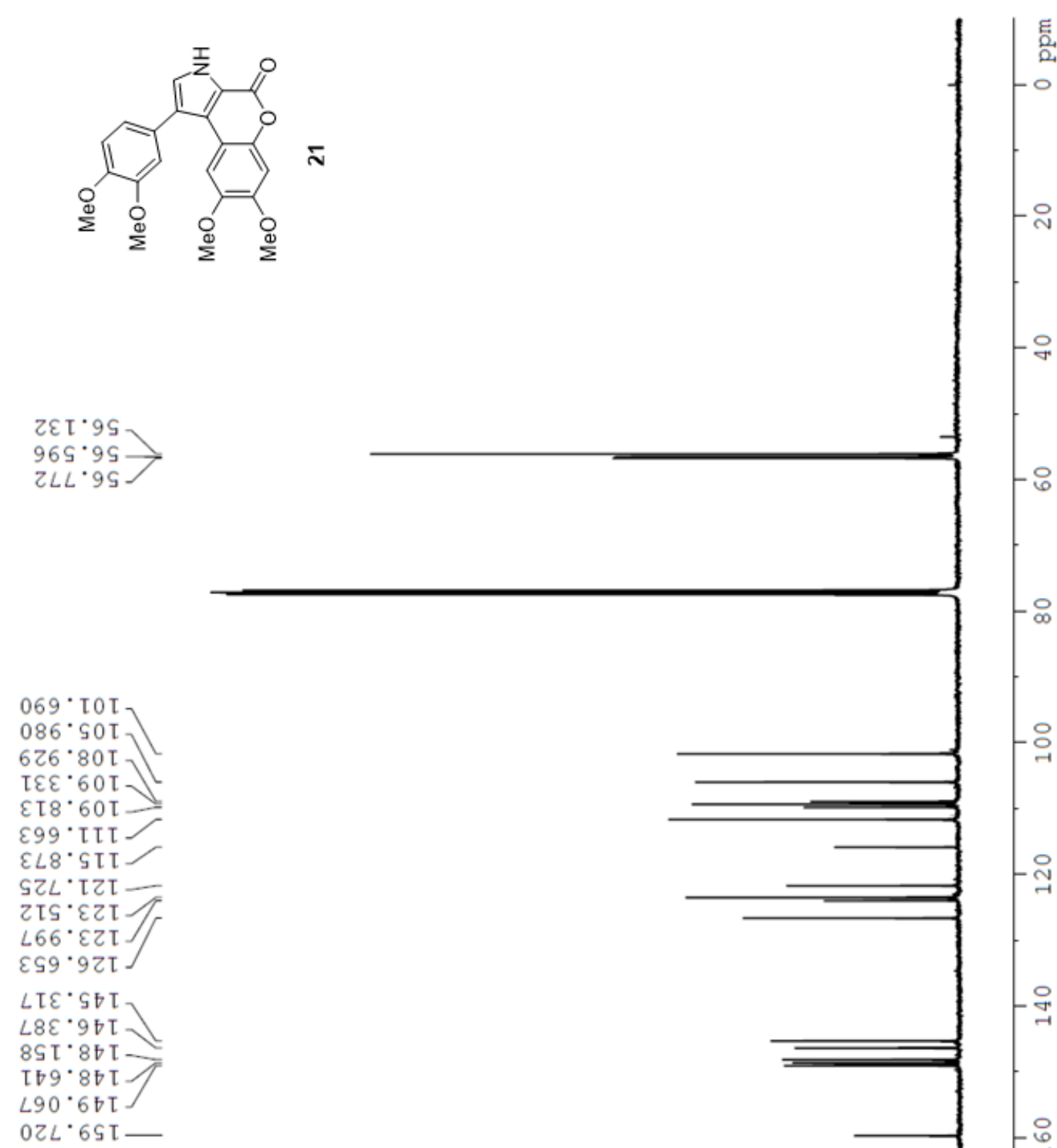
<smiles>COc1ccc(CC[Z]2cc(-c3ccc(OC)c(OC)c3)c3c2c(=O)oc2cc(OC)c(OC)cc23)cc1OC</smiles>
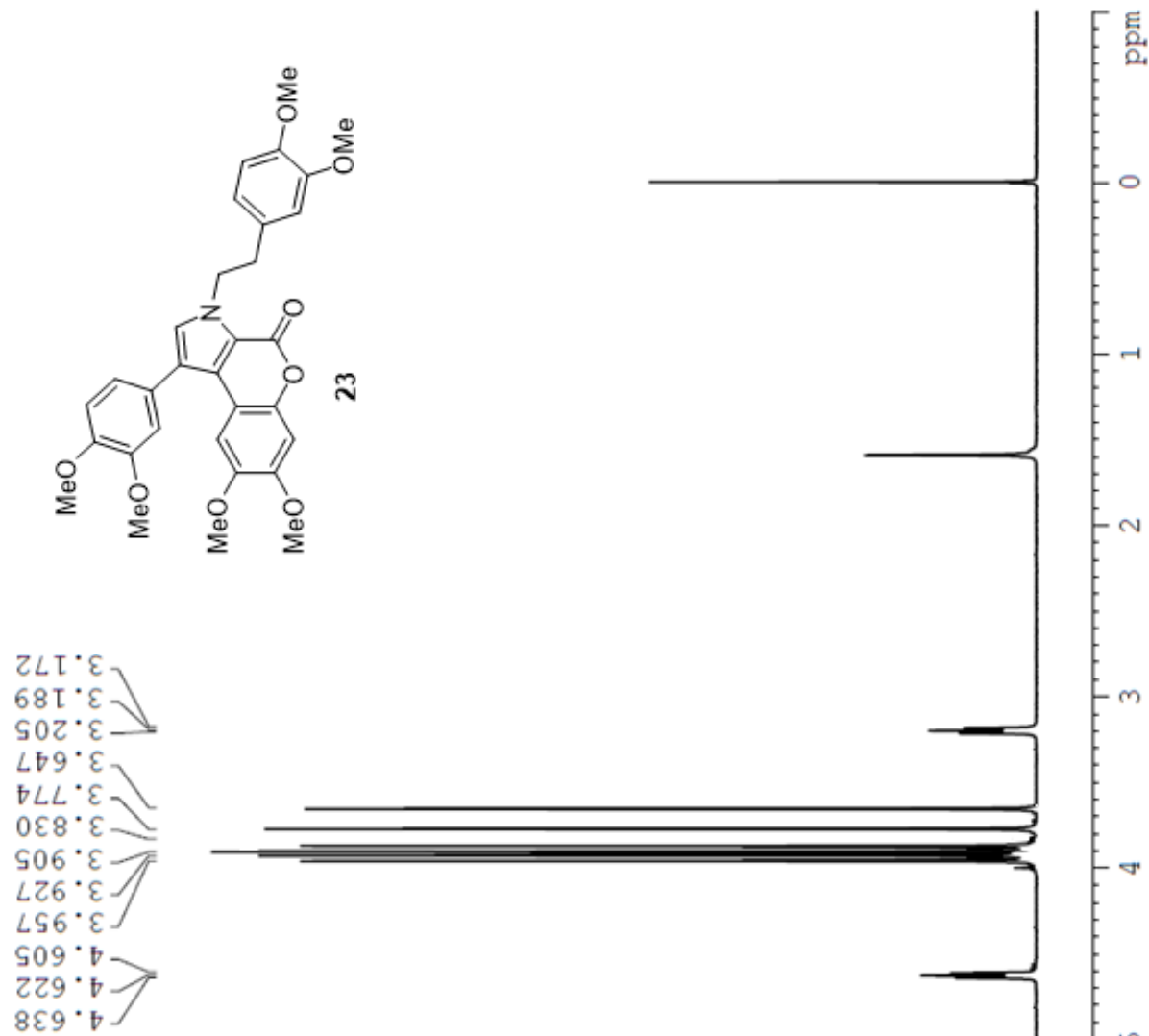

$-m$

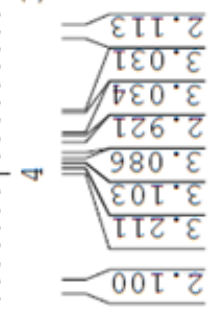

SLS. 9
$6 L S \cdot 9$

$\angle 69^{\circ} 9^{\circ}$

$9 \mathrm{~T} L \cdot 9$

$6 \varepsilon L .9$

$\angle 8 L^{\circ} 9$

$908^{\circ} 9$

$568^{\circ} \cdot 9$

$0+66^{\circ} 9$

IS6.9

$696^{\circ} 9$

$\checkmark L 66^{\circ} 9$

$060^{\circ} \mathrm{LJ}$
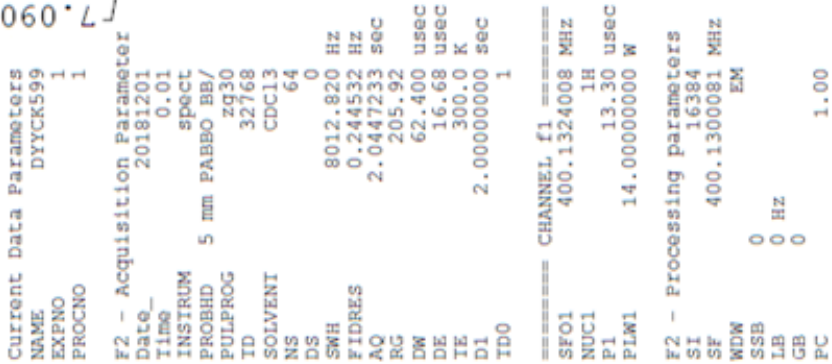

- in

$N$

2

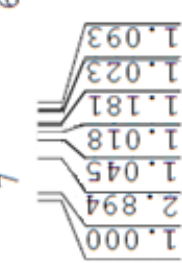

$-\infty$

a 


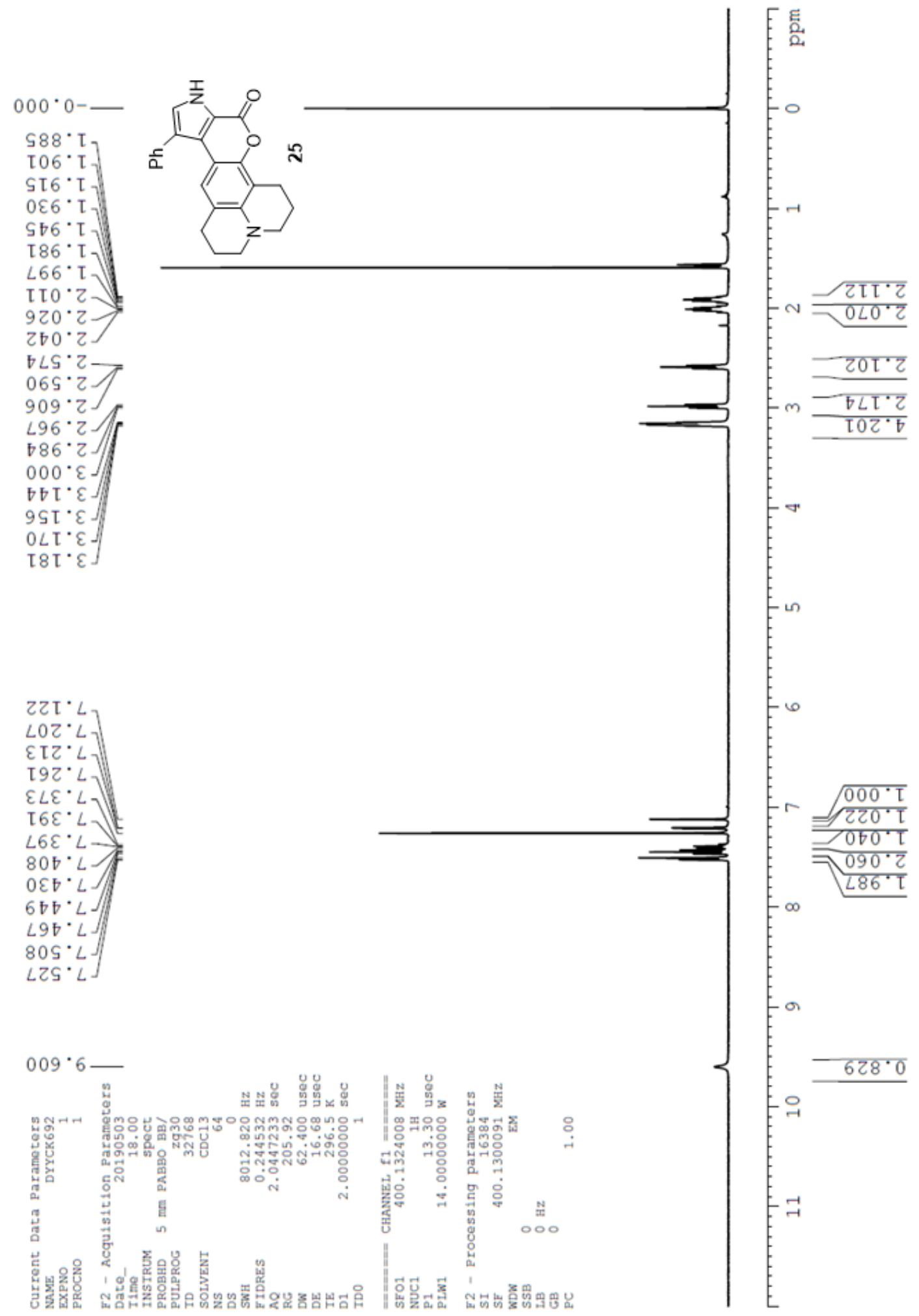




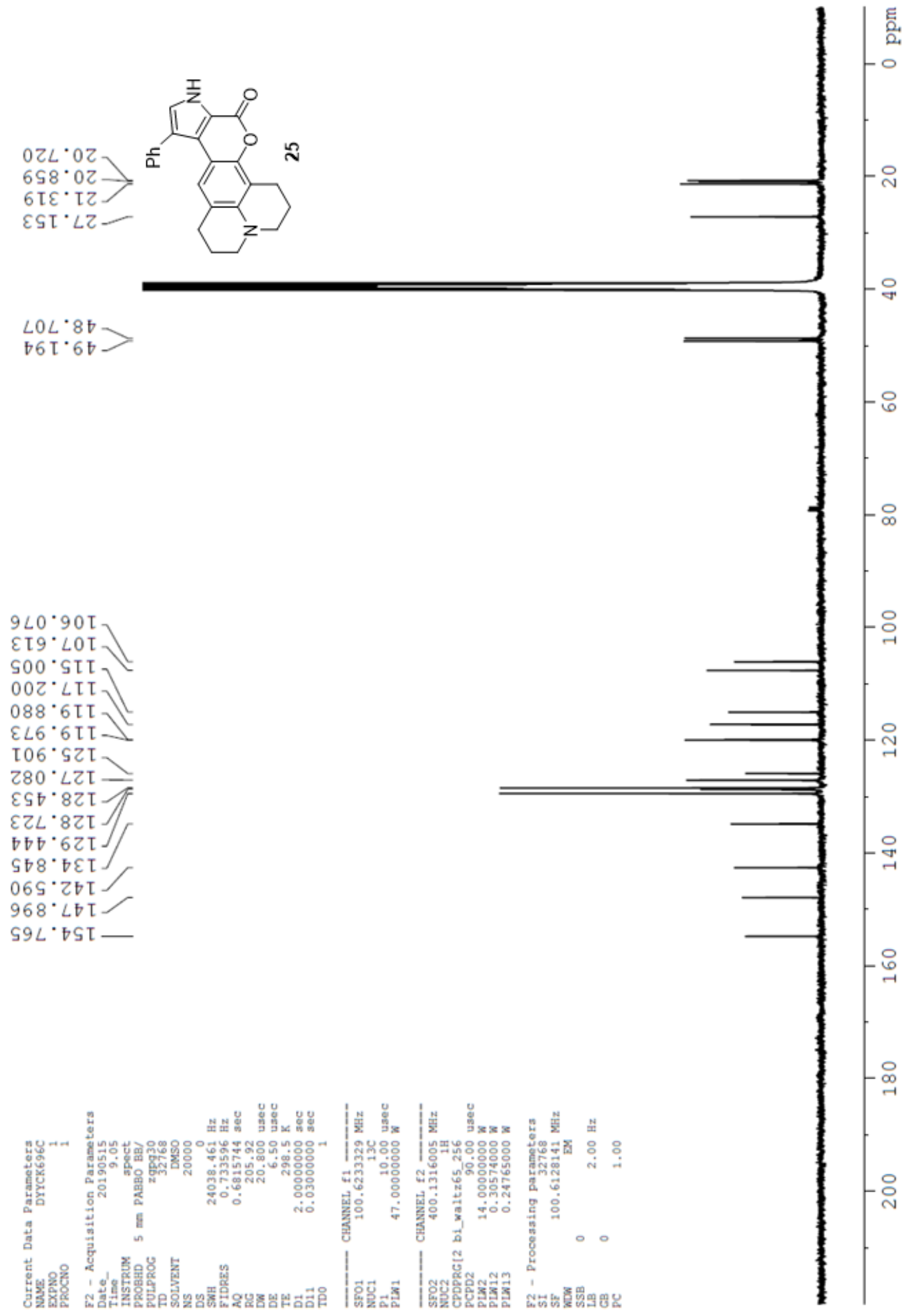




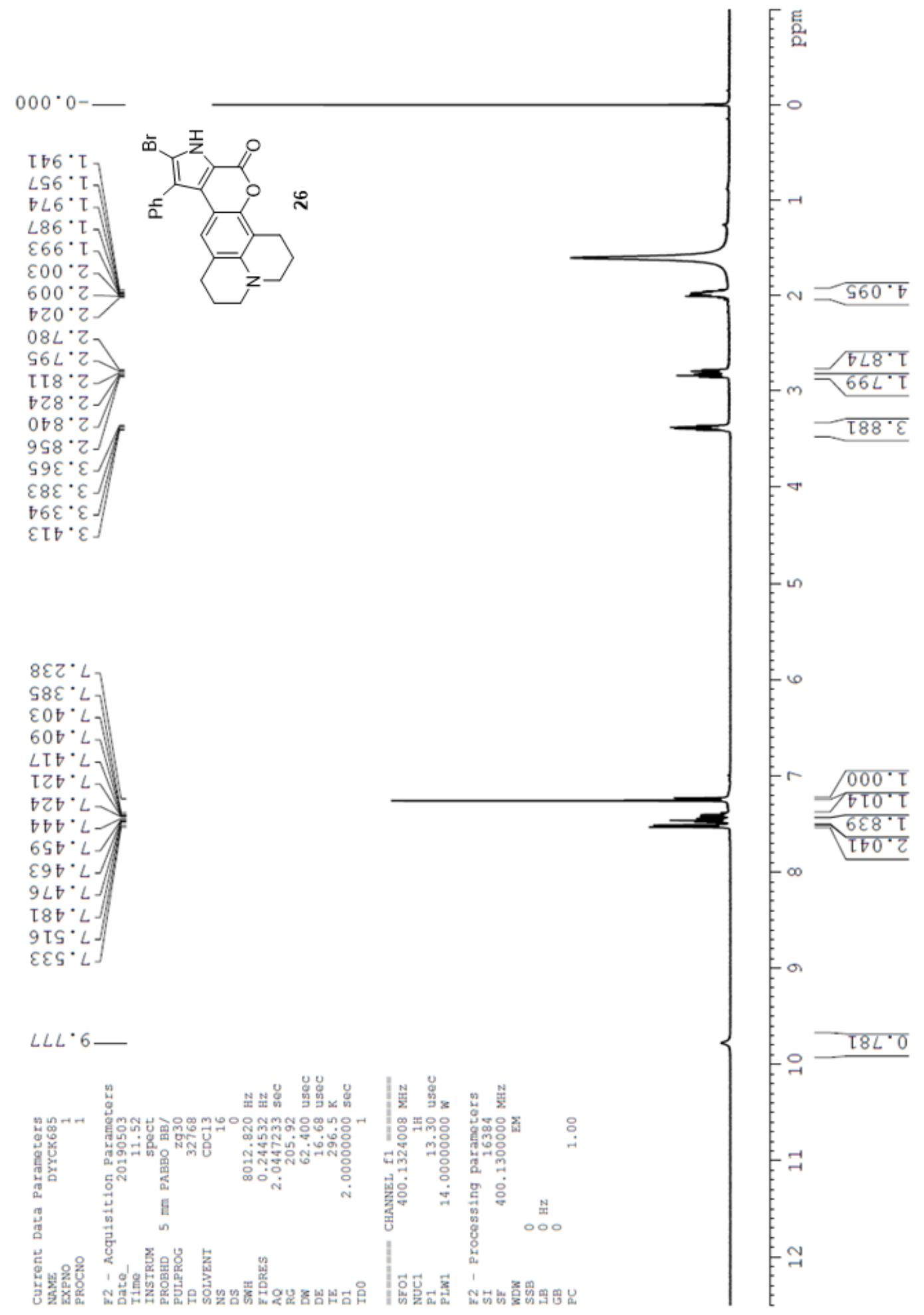




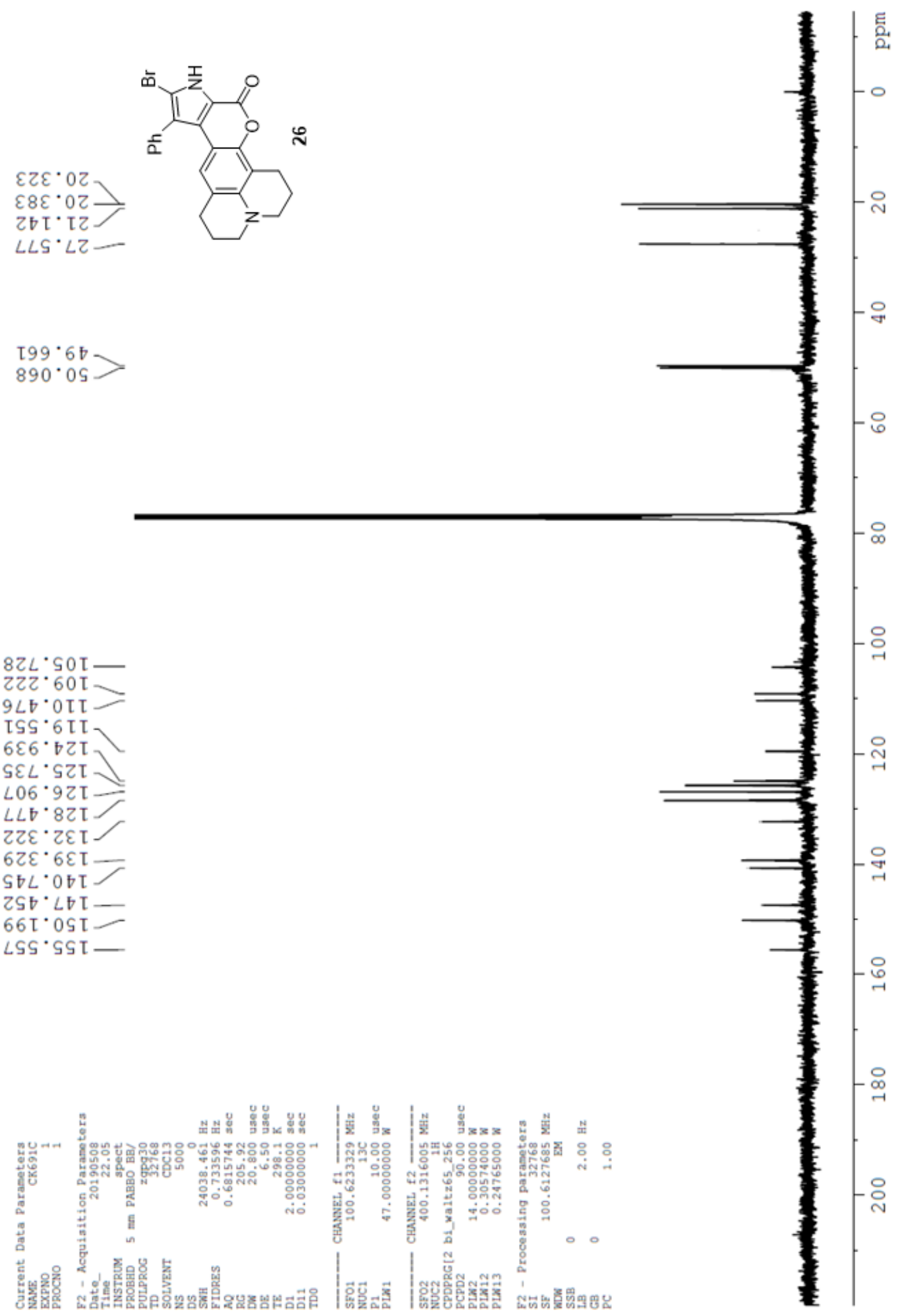




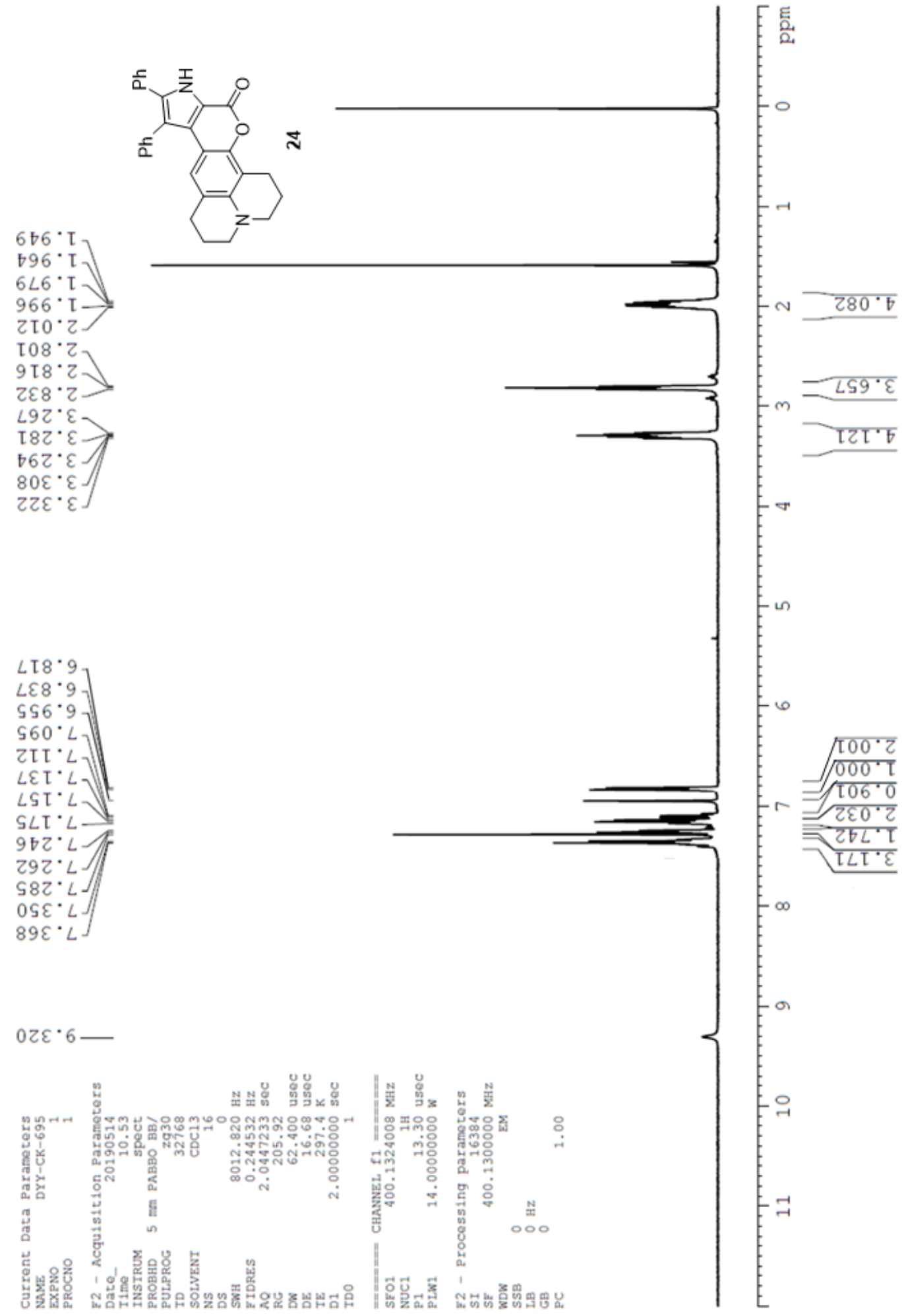




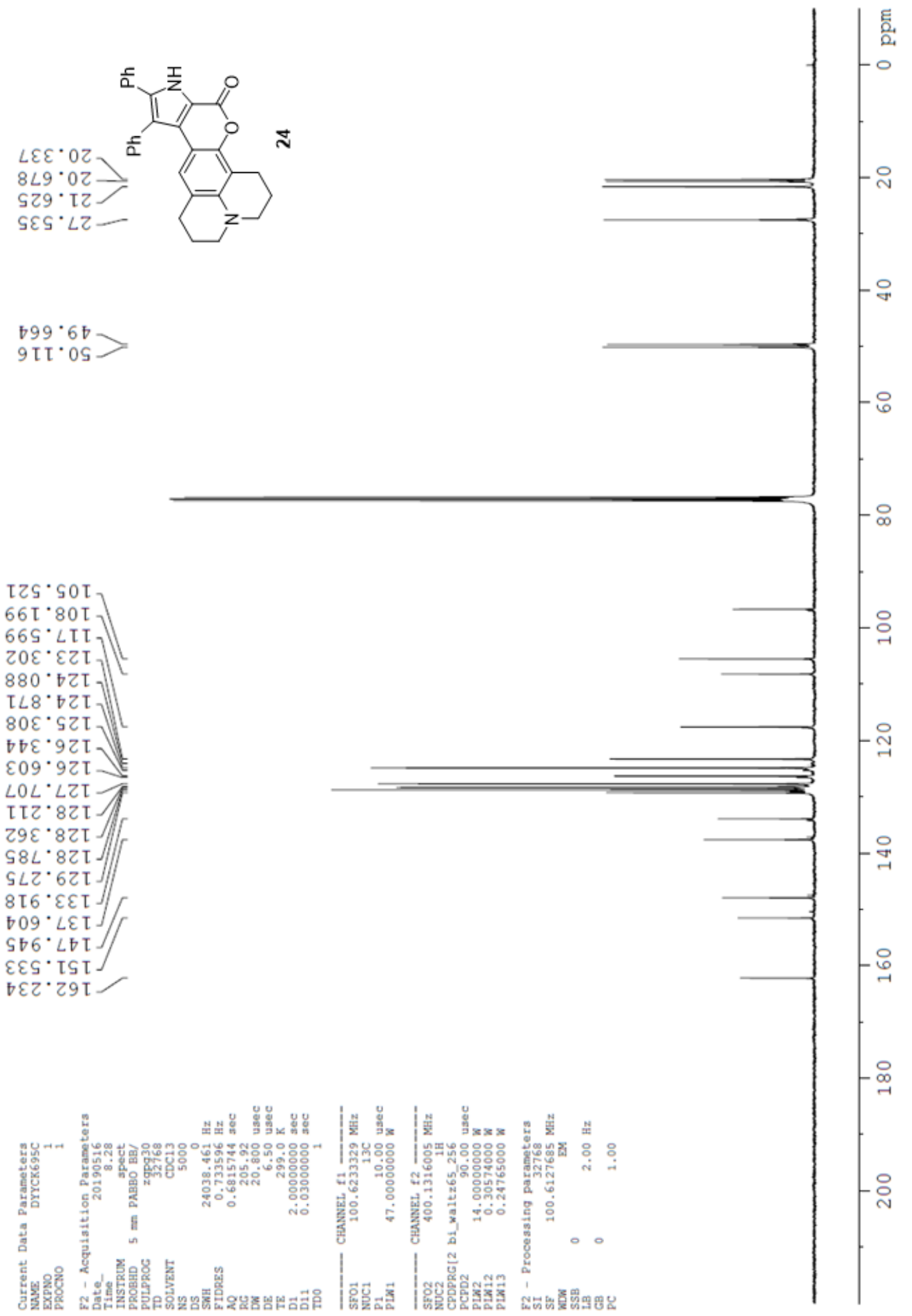


7. Proton NMR spectrum comparison of ningalin $B$ with literature.

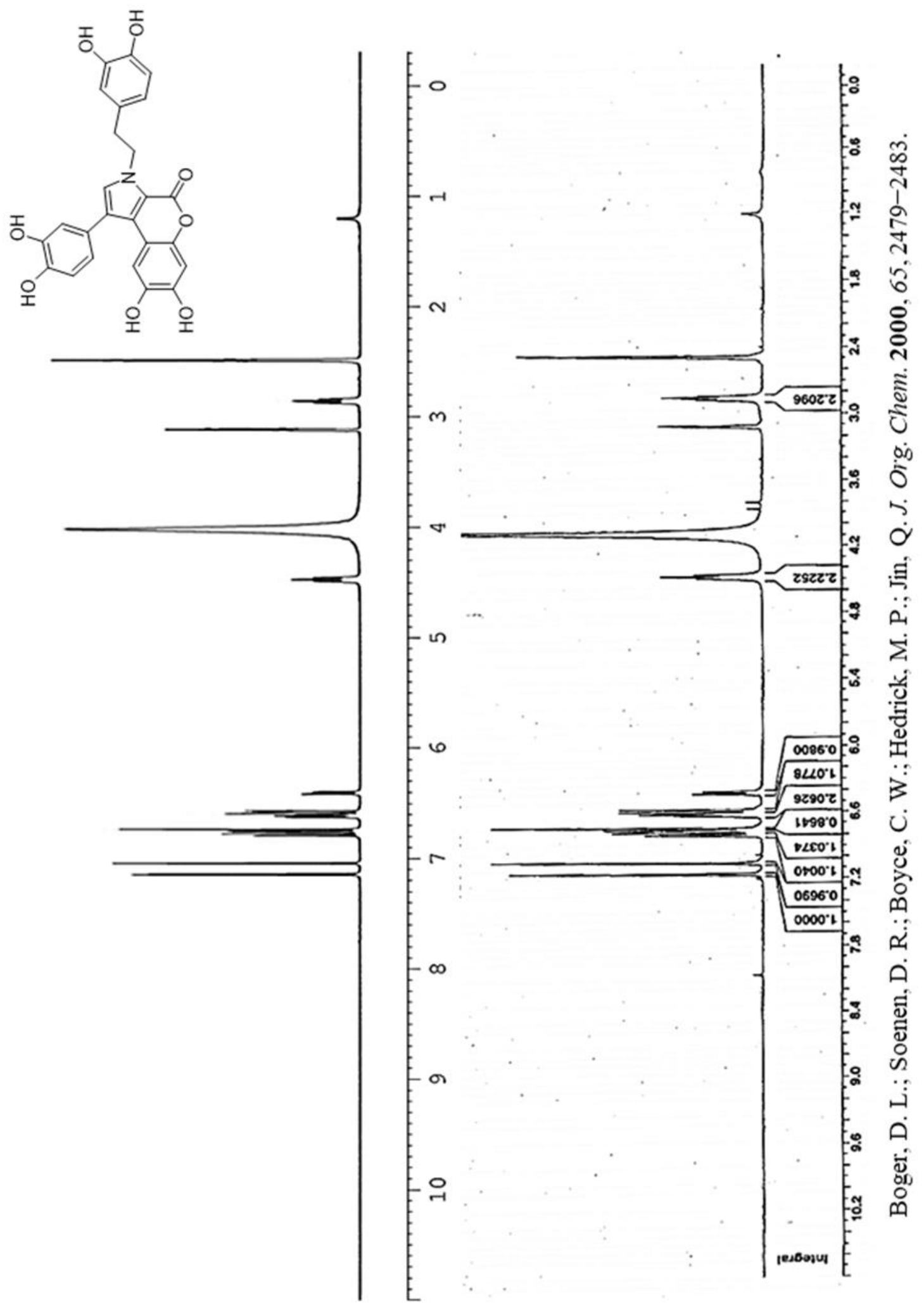

